\title{
DIVISION INTO HORIZONTAL STRATA OF THE LANDSPACE ABOVE THE SURFACE*
}

\author{
STUART S. BALL
}

$I$

The following propositions have been elsewhere advanced:

(1) The real "land" in law is three-dimensional space, containing solid matter treated as realty because of more or less permanent occupancy of a defined space. ${ }^{1}$

(2) The right of ownership is the right to the ultimate possession of the thing owned.2

(3) The courts in most common law jurisdictions have recognized rights of ownership in the space both superjacent and subjacent to the surface of the soil. ${ }^{2}$

Assuming for the moment the truth of these propositions, the problem to which a solution is now sought may be formulated: Can the superjacent landspace be divided by horizontal planes into strata capable of several ownership?" Since land has no natural boundaries, but is always separated by artificial and arbitrary means, it would be no more arbitraiy to divide it in this way than to divide it, as we now do, by vertical planes, once we assume or conclude that space is the real "land." Have we any precedents? It is purposed to demonstrate that we have.

The test to be applied to the cases must take into account the following considerations: A man may have the right to use the space of another without depriving that other of ownership; he may own a material thing occupying space owned by another; and he may be given the present possession of a portion of another's space without being given the ownership of it. We must reject cases which illustrate these situations but which do not

\footnotetext{
* Considerable labor in seeking and checking authorities, as well as in preparing the body of the article, was contributed by the writer's brother, Mr. Ralph K. Ball, of Evanston, Illinois.

2 Ball, The Jural Nature of Land (1928) 23 Irt. L. REv. 45.

2 Ball, The Vertical Extent of Ownership in Land (1928) 76 U. OF PA. I REv. 631, 644 et seq.

3 Ibid.

* The following remarks, written in 1862, show that the problem had occurred to members of the profession that early:

"First, as to this space or column of air over a man's land. ... Wo know of no case in which an effort has been made by grant or convoyance to sever it from the soil and give an exclusive right in it, in the manner in which, as we shall presently show, the herbage or mineral strata may bo severed from the body of the ground." E. S. M., Horizontal Divisions of Land (1862) 1 AMr. L. REG. (N. S.) 577, 578.
} 
hold that ownership of a portion limited horizontally as well as vertically has been carved out of the original lot.

When a room or an apartment is leased, is it the cubic space of the room which is demised or only the floors, walls, and ceilings?: If the latter, the lease would include by implication the grant only of a right in the nature of an easement to use the space so inclosed. The lease of rooms has been held to give the right of exclusive possession to the lessee. ${ }^{\circ}$ It seems reasonable to assume that the right should extend to the inclosed space, but unfortunately no practical test is afforded by the cases. Our present interest in this proposition lies in an inference which could be drawn from proof of the afiumative. Since ownership

\footnotetext{
5 There can be a leasing of a floor, or of a suite of rooms, or of single rooms, creating a true tenancy with all of its incidents, including the right to bring trespass. In White v. Maynard, 111 Mass. 250, 254 (1872), MIr. Justice Gray said:

"An entire floor, or a series of rooms, or even a single room may doubtless be let for lodgings, so separated from the house as to become in fact and in law the separate tenement of the lessee."
}

To the same effect are: Swain v. Mizner, 8 Gray 182 (Mrass. 1857); Lane v. Dixon, 3 C. B. 776 (1847); Stamper v. Sunderland-near-the-ses, I. R. 3 C. P. 388 (1868).

This rule would apply to our modern apartments: Davis v. \#artel, 56 Pa. Super. 557 (1914); IIcDowell v. Hyman, 117 Cal. 67, 48 Pac. 984 (1897). In the last cited case, the court remarked:

"Flats are as much separate dwellings as ordinary adjoining houses are. The difference is that fiats are under one roof, and are divided one from another by a horizontal plane, but ordinary adjoining houses by a perpendicular or vertical plane." Ibid. 71, 48 Pac. at 986.

6 A lease of rooms, creating the relation of landlord and tenant, must be carefully distinguished from agreements creating only the relation of lodger and lodging house keeper. Very frequently one who occupies a room or a suite of rooms is not a tenant but a lodger. The distinction is important to remember at this point of our discussion, since, as was said in IIathews v. Livingston, 86 Conn. 263, 267, 85 Atl. 529, 531 (1912): "The tenant has the exclusive possession of his rooms, while the lodger has merely the use without the actual or exclusive possession which remain in the lessor." Accord: Miesserly v. ITercer, 45 IIo. App. 327 (1891); Fludier v. Lombe, Lee \& H. 307 (1736); Brewer v. IICGowan, I. R. 5 C. P. 239 (1869); Green v. Shoemaker, 111 IId. 69, 73 Atl. 68 (1909). As a consequence, the lodger can bring neither ejectment nor trespass. Allen v. Overseers of Iiverpool, I. R. 9 Q. B. 180 (1874); Wilson v. Mrartin, 1 Denio 602 (N. Y. 1845); Miathews v. Livingston, supra; White v. IFaynard, supra note 5 .

In denying trespass to a lodger, in Iane v. Dixon, supra note 5 , Mir. Justice Iraule speaks of the lodger's right as a "mere easement of sleeping in one room, and eating and drinking in another." Ibid. 784. For the basis of the distinction, of. Fox v. Windemere Hotel Apartment Co., 30 Cal. App. 162, 157 Pac. 826 (1916); Commonwealth v. Lynchburg Y. IF. C. A., 115 Va. 745, 80 S. E. 589 (1914); Dewar v. Irinneapolis Lodge, 155 Minn. 98, 192 N. W. 358. (1923). See also Tote ArN. CAS. 1914A 200, in which reference is made to a considerable list of English cases; and TIFFANY, I.ANDEORD AND TENANT (1st ed. 1910) § 8 . 
is no more nor less than the right to the ultimate possession, it follows that, if we can conceive of the stratification of cubic space for purposes of possession, we can conceive of it so divided for purposes of ownership. There is, however, considerable reason for believing that leases of rooms are not in reality treated by the courts as a grant for a term of the possession of the space enclosed. ${ }^{7}$ If so, we must find support for our general proposition elsewhere. ${ }^{8}$

IIn the case of a demise of rooms for years, it is generally recognized that the destruction of the building terminates the lease. MicMillan v. Soloman, 42 Ala. 356 (1868); Ainsworth 7.. Ritt, 38 CaI. 89 (1869); Stockwell v. Hunter, 11 Mietc. 448 (Mass. 1846); Kerr v. Merchant's Dxchange Co., 3 Edw. Ch. 315 (N. Y. 1839) ; Graves v. Berdan, 26 N. Y. 498 (1868); Rowan v. Kelsey, 2 Keyes 597 (N. Y. 1866); Winton: v. Cornish, 5 Ohjo 477 (1832) ; Hilliard v. Gas Coal Co., 41 Ohio St. 662 (1885).

The reasoning of these cases is typified by this remark from the McMillan case, supra at 364: "Where there is a lease of-the mere apartments of a house, and those apartments are destroyed, the thing rented is gone."

It has been held that when a demise of rooms is made, tho walls aro included in the demise. Hope Bros., Ltd. v. Cowan, [1913] $2 \mathrm{Ch} .312$; Goldfoot v. Welch, [1914] 1 Ch. 213.

In Leiferman v. Osten, 167 Ill. 93,47 N. I. 203 (1897); the lessee of rooms remained in possession even though the building containing them was moved to a different part of the lot. Clearly he had lost his occupancy of the space enclosed by the room when originally leased; but the court held that the moving of the building did not constitute an ouster, saying: "It does not appear that he was deprived of anything that could reasonably be held to pertain to his lease of the "first flat' of No. 1255 Wolfram St." Ibid. 100, 47 N. E. at 205.

8 Wo cannot find such support in the rule that buildings, although ordinarily in law a part of the land on which they are erected, may, by an express agreement to the contrary or by the implications of an agreement giving the right to removal at the expiration of the license to use the land built upon, be separately owned; for they then become personal proporty. It is obvious that we are dealing with the difference between fixtures and affixtures, and that our only concern is with the title to the chattels which have entered into the building of the house. The cases are too numorous to be cited here. See, generally, 22 RoLING CASE LAW 59, § 33 ct sog. An excellent summary is to be found in Note (1909) 12 ANN. CAS. 1088. 1 THOMIPSON, REAL Property (1st ed. 1924) § 61 misstates their effect.

Before the Reception, the Germanic law permitted, buildings to be soparately owned, but they were then treated as movables and not as immovables. HUEBNer, History of Germanic PRIVATE LAW (Cont. Leg. Hist. Series, 1918) 172-3. Hübner suggests that this rule arose in a day whon buildings were far. less permanent, and their builders more nomadic. Tho old Germanic notion took root for a while in Italy in the height of the Germanic infuence on Italian politics; but the Roman conception of the unity of the principal thing and its accessories gradually overcame it. The mediaeval communes, in effectuating the return to the Roman law rule, even enacted legislation providing for purchases and sales necessary to reintegrate ownership of all parts of the thing. CALISSE, HISTORX OF ITALIAN LAW (Cont. Leg. Hist. Series, 1928) § 415, p. 671.

The fact that courts, as in Oskaloosa Water Co. v. Board, 84 Iowa 407, 
II

The cases involving freeholds in chambers or apartments must be considered. When a room or suite of rooms is deeded separately from the soil beneath, either one of two results is conceivable:

(1) A right of ownership is created which relates to the ma: terial definition of the room-the walls, floor, and ceiling-and is coupled with either an easement or possessory right relating to the space inclosed.

(2) A right of ownership is created relating to the space inclosed as well as to the inclosing matter.

If the latter.alternative be adopted as the solution, a practical question arises in the event of the destruction of the building in which the rooms are located. If the rule be that ownership ceases, it is still possible to say that the space was owned in fee, but it follows that the fee was defeasible by a condition subsequent. The emphasis is placed, not on the space, but on that which bounds the space. The walls are what is important. If destruction defeats the fee, it is less complicated to hold that an easement or possessory right in the space, not ownership, follows ownership of the walls, and that the owner of the lot retains the fee to his solid land column.

If the space be truly owned, logic does not demand that ownership be affected by the destruction of the building. Space, being conceptual, is not affected by the history of matter existing in it. Ownership, as a right relating to a thing, need not be affected by the destruction of the inclosing walls, since the thing which is the point of reference, the bit of space, remains intact.

It should be frankly recognized that, in the case of a grant of an upper room, we are dealing with an exception to the normal operation of legal rules, even though the common law jurisdictions have never applied the maxim superficies solo cedit. as inexorably as have those jurisdictions with a purely Roman tradition. Probably there was a time when the English courts would not have upheld the conveyance of an upper chamber. ${ }^{0}$ The

51 N. W. 18 (1892), sometimes hold such buildings taxable as "realty" does not bear on our question.

"We find in Brooke's ArdDgement (1586) tit. "Demaunde," pl. 20, fol. 213, reference to a case in the year books, 5 HEN. VII, 9, where, in answer to a suggestion that a man might have a franktenement in an upper chamber, it was said that such could not be, for it could not continue, since, if the foundation failed, the chamber would be gone.

A note by Sweet, editor of the third edition, in Charlus, IAN OF RaAr Properry (1911) 48 et seq., refers to this. Sweet regards the rule permitting chamber ownership as a "heresy" which has found its way into the common law, because he believes that it is inconsistent with and an exception to the rale that corporeal hereditaments are indestructible. This is a 
change in attitude which has occurred, curiously enough, reflects a custom prevalent among the members of the legal profession sharing the privileges and fellowship of the Inns of Court. Originally, the chambers in the Inner and Middle Temples were in effect leased to those to whom they were assigned. The early admittances noted in the records appear to have been made upon this basis. A considerable amount of building construction was made during the reign of Elizabeth, for the growth of the Temple societies made necessary more chambers. The societies were not able to finance such expansion, and the difficulty was solved in the fashion indicated by the following entry in the minutes of the parliament of the Middle Temple:

"The chambers which Mr. William Herbert, one of the fellows, will build on the site of the old kitchen, shall be granted to him alone for life, and no one else shall be admitted thereto by the Treasurer during his life. . . He may assign or leave by will these chambers to any fellow or fellows, who shall hold them similarly." 10

0

Many similar entries are to be found in the Temple records of the period, and the practice soon became so prevalent in the Middle Temple that it practically superseded the former leasings. ${ }^{11}$

clear acknowledgment that he considers the thing owned as the portion of the material building conveyed. He emphasizes this view by the following sentence:

"It seems clear on principle that, if the house is burnt down or otherwise destroyed, the rights of the owner of the upper chamber cease, but tho point does not appear to have been decided." Ibia. 54 .

101 MLDDLE TEMPLe RECORDS (Hopwood's ed. 1904) 207: minutes of a parliament of the Temple of Nov. 17, 1575 (17 Fliz.).

11 A number are cited and discussed in Williamson, The HISTORY of the TEMPLE, London (1924) 227, 228, 234, 235, 236, 291 and 292. Williamson says, concerning this activity:

"Probably the Society had little money to spend on such enterprises, for new chambers at this time were generally erected by individual members at their own expense, the Benchers in return acknowledging a certain proprietary interest in the member who had incurred the outlay. Lator it became the regular practice to give the builder a life interest, with the right to make one or more assignments to take effect thereafter." Ibid. 227.

These remarks were prompted by entries around 1578. In 1577 thero is an entry indicating that all Masters of the Bench in the Middale Templo were to have their bedchambers for life. In the first decades of the 17th century attempts were made to stop this private building so that the Temple could have the sole letting of the rooms.

One odd circumstance is that the societies did not have a fee interest in the inns at this time, for they were then paying a nominal yearly charge to the Crown, and did not until later (1608) completely acquire the properties.

Dugdale, describing the manner of life in the Middle Temple, spoke of the "ancient usage and custume of the house" by which one admitted to a 
The justices, intiated in the custom by the circumstances of their apprenticeship in the profession, could no longer regard the idea of a freehold in an upper chamber as a strange and impossible one. In 1638, two men were arraigned for breaking and entering a barrister's chambers. The reporter says:

"And first, it was resolved that a chamber of any inns of court or chancery broken open may be said to be domus mansionalis of him who is owner of the said chamber." 13

By this time the custom must have bred counterparts among the laity of growing London. We are not surprised, therefore, to find Lord Coke telling us:

"A man may have an inheritance in an upper chamber, though the lower buildings and soile be in another, and seeing it is an inheritance corporeall it shall passe by livery." 25

Shortly after Coke wrote, ejectment was allowed in Ford $v$. Lerfie $^{14}$ for a house, a bain, and a kitchen. The part most doubted was the kitchen, but the court pointed out that, since it had been held that there could be a frank-tenement in an upper room, so there could be ejectment for a kitchen. ${ }^{15}$

chamber had it for life with power to sell it to another member to hold upon the same conditions. DUGDAIE, ORIGINEs JuRIDICares (printed in 1790 as "Historical MIemorials of the English Laws") 88. It is not clear whether Dugdale intends to imply that only benchers so hold a life interest. He tells us that "all but the benchers go two in a chamber; $a$ bencher only hath the privilege of a chamber to himself," The next sentence may refer either to all in chambers, or only to those benchers who are admitted to one for themselves alone.

Dugdale has it that the interest could be forfeited: ". . . for unless he be in commons six weeks in each year, he forfeits his chamber to the house." This is in direct contradiction to the grant to MIr. William Herbert, part of which is quoted in the text, and to many of the other similar entries. It may be that Dugdale has failed to distinguish the old chambers, presumably still let by the house, from the new ones built in accordance with the proprietary grants; or possibly the system he described resulted from the abolition of the differences in the two tenures by the passing of years.

12 Evans \& Finch's Case, Cro. Car. 473 (1638). This case has been cited many times by the English courts in support of the separate rating of the various "houses" in tenements, although the separate holdings there involved are generally let premises.

13 Go. LiTT. *42b. So, too, we are told in the Touchstone that: "A feoffment may be made of an upper chamber over another man's house beneath." Sheppard, Touchstone (1651) 206; cf. similar language in 1 Preston, ESTATES (1828) 8. The passage from the Touchstone is quoted with approval in IIott $\nabla$. Palmer, 1 N. Y. 564 (1848).

14 Noy 109 (1604).

15 Accord, as to right to bring ejectment for a room: Brady $\mathrm{v}$ Kreuger, 8 S. D. 464, 66 N. W. 1083 (1896); White v. White, 16 N. J. L. 202 (1837). And see the language quoted in the text from Mradison v. Iradison, infra note 17. 
In 1787, Mr. Justice Ashurst remarked:

"We know that in London different persons have several freeholds over the same spot; different parts of the same house are let out to. different people. That is the case in the Inns of Court." to

Here the recognition of the rule was coupled with a reference to its origin. In that case, the rule was invoked to show that a conveyance of a shop did not include the cellar beneath, which had been separately demised previous to the conveyance. The case is the leading one in England in support of the rule that a room can be separately owned.

We find numerous cases in this country to the same effect. In holding that the upper stories of a brick opera house, which were conveyed by deed by the owner of the soil and lower stories, constituted real estate so as to give the grantee all the rights of an owner of land, the Illinois Supreme Court said:

"A house, or even the upper chamber of a house, may be held separately from the soil on which it stands, and an action of ejectment will lie to recover it." ${ }^{17}$

In its reasoning, the court attached great weight to the fact that there was no way of removing the upper stories, and seemed to be aided in reaching the decision by that fact. The inference is that the thing conveyed was the part of the physical structure and not the landspace.

In an Iowa case, ${ }^{18}$ the homestead exemption statute was made to work a separation of a first floor and cellars from the second and third stories and the soil. The first floor was occupied by shops, and the cellars were used in connection with the shops. The defendant in execution occupied the second and third stories for his home. It was held that the second and third.stories and the soil were exempt as a homestead, but that the first floor and

10 Freeland v. Burt, 1 T. R. 701' (1787). The word "let" here refers to more than a leasing, since the court in the next sentence discussed a leaso to a third party of the chambers which had been purchased.

${ }_{27}$ Madison v. Madison, 206 Ill. 534, 537, 69 N. E. 625, 627 (1903).

In Piper v. Taylor, 48 N. D. 967, 970, 188 N. W. 171, 172 (1922), an association paid the consideration for the erection of a second story, took possession on completion, paid the taxes, and kept up the insurance in its own name. The court said:

"The owner of the land intended that the association should own the second story. He would have deeded the same to the association except for the advice received that such could not legally be done. This advice was erroneous. Caldwell could have granted or reserved the second story alone, as the parties desired. Real estate may be granted or leased divided upon perpendicular or lateral lines."

18 Rhodes, Pegram \& Co. v. McCormick, 4 Iowa 368 (1857). 
cellars, not being within the exemption because of the use to which they were put, were liable to be sold on execution. In enumerating the rights of the purchaser on execution, the court said:

"The purchaser under the execution acquires the right to the possession of the first floor and cellar and every part of each; which right is to continue as long as the same is tenantable." 20 (Italies ours)

19 Ibid. 375-376. A similar result of the operation of the Iowa homestead law was sustained by the state supreme court in two later cases: Ifayfield v. Mraasden, 59 Iowa 517, 13 N. W. 652 (1882); Johnson v. Iroser, 66 Iowa 536,24 N. W. 32 (1885). In other cases the Iowa court has reached a different result, not ostensibly because of a changed interpretation of the homestead law, but because the evidence did not show a sufficiently definite separation in use of the living quarters from the other parts of the building. Wright v. Ditzlex, 54 Iowa 620, 7 N. W. 98 (1880); Smith v. Quiggans, 65 Iowa 637, 22 N. W. 907 (1885); Cass County Bank v. Weber, 83 Iowa 63, 48 N. W. 1067 (1891); Buckles v. Iratson, 178 Iowa 310, 159 N. W. 1007 (1916). In the Iast cited case, Mir. Justice Gaynor spole of the rule of the Rhodes case as "of very doubtful propriety."

The courts of several other states have refused to follow the Rhodes case in interpreting their homestead laws. Phelps v. Rooney, 9 Wis. 70 (1859); 12 Wis. 698 (1860) (on rehearing); Norris v. Kidd, 28 Ark. 486 (1873); Smith v. Guckenheimer, 42 Fla. 1, 27 So. 900 (1900). In the first case, Mr. Chief Justice Dixon vigorousiy dissented on the rehearing, argaing that the common law rale permitting the division of ownership led logically to the conclusion reached by the Iowa court. A federal court, construing the Iowa homestead law in a bankruptcy case, criticized the Rhodes caso and refused to follow it, attempting as well to distinguish its facts. In re Coles, 224 Fed. 170 (N. D. Iowa 1915). It should be observed that the quarrel other courts have sometimes had with the Rhodes case is because they believed the result inconsistent with the purpose and spirit of the homestead exemption statutes and not because they did not believe that the lan can recognize divided ownership of a building.

The Illinois Supreme Court has approved the Rhodes case in Potter v. Clapp, 203 MII. 592, 68 N. E. 81 (1903). The opinion of IIr. Chief Justice Hand is interesting because it shows that the growth of large apartment buildings does influence the court to recognize such stratifications:

"While in a case like this it might work no great harm to hold the widow after the death of the householder might rightfully retain the possession of the entire building until her homestead was assigned, if the principle were applied to a building containing, as is often the case in large cities, many flats or apartments, it would lead to absurd results." Ibid. 605, $68 \mathrm{~N}$. L. at 85.

The same premises as in the Rhodes case were involved in IfCCormick $v$. Bishop, 28 Iowa 233 (1869), and it was held that the purchaser under the execution sale of the first floor and cellars vas not a tenant in common with the owner of the exempt homestead; but that the two owners were adjoining tenants, with several and divided interests. In the case of a similar separation, differently effected, the Illinois court also denied that any joint estate existed. IICConnel v. Kibbe, 43 III. I2 (1867).

The complete separation in law of the two freeholds which can thus be created was further emphasized in Badger Lumber Co. v. Stepp, 157 MIo. 366,57 S. W. 1058 (1900), where a third story was separately orned from 
The limitation indicates that rights of ownership would be defeated by the destruction of the building. Indeed, this seems to be the tendency of many of the cases. In them we can find little or no comfort for a belief that space above the soil is susceptible of ownership in horizontal strata. ${ }^{20}$ In other cases, the implications are somewhat more favorable.

the lot and remainder of the building, and a contractor's lien was said to be valid against only the part on which work was actually done.

20 Thus, in Thorn v. Wilson, 110 Ind. 325,11 N. E. 230 (1886), the first party was to erect a one story building, and granted and allowed the second parties "to build and complete a story ... on top of the above mentioned first story of said building ... to have and to own said second story of the said building for the use of the parties of the second part perpetually." The court treated this as a grant merely of an easement, a "right to perpetually use the second story" so that "when the use terminated, all their interest in the building was gone so that they could convey none by deed."

The view that a grant is terminated by the physical destruction of the premises is adopted in 1 Thompson, REAL Property (1st ed. 1924) 60; of. also the remarks to be found in Sweet's note to CHaLLIS, RanL ProperTr, supra note 9.

The separate ownership of upper chambers has been recognized in a number of cases where the issues had to do with the mutual rights of support and repairs as between the upper and lower freeholders. It has always been recognized that the owner of an upper chamber has such a right to support from the walls below that any act of the lower ownor endangering the stability of the upper tenement is an actionable wrong. Anonymous, Keilw. 98, pl. 4 (1508) ; Bush v. Field, Cary 90 (1580); Anonymous, 11 Mod. 7 (1702); Loring v. Bacon, 4 Mass. 575 (1808); Cheeseborough v. Green, 10 Conn. 318 (1834); Ottumwa Lodge v. Lewis, 34 Iowa 67 (1871); Jackson v. Bruns, 129 Iowa 616, 106 N. W. 1 (1906); McConnel v. Kibbe, 33 III. 175 (1864). In the last case cited, which involved the same premises as McConnel v. Kibbe, supra note 19, it was hold that the removal of support was in itself such an infringement of the upper

- proprietor's right as to obviate the necessity of showing special damage.

The anonymous case in Keilwey, supra, also suggests that, if I am a lower proprietor, I may compel the upper de coven son haute meason on salvation del timber de ma meason; and vice versa, if I am an upper ownor, my right to support may be broad enough to entitle me to demand that the lower owner repair his timbers. If the law be that way, the proper remedy, said the judges, was an action on the case. In the later anonymous caso in 11 Modern, supra, Holt, C.J., is reported to have said that "every man, of common right, ought to so support his own house as that it may not bo an annoyance to another man's."

In this country it seems to be generally agreed that no right to demand repairs to the roof or supporting walls exists. Cheeseborough v. Green; Jackson v. Bruns, both supra; Weaver v. Osborne, 154 Iowa 10, 134 N. W. 103 (1912); Pierce v. Dyer, 109 Mass. 374 (1872). See 1 TIFfaNX, Reax PROPERTY (Ist ed. 1920) $\$ 355 ; 1$ C. J. 1232. Conversely, it has been hold that if the owner of the upper story repairs his roof, or the owmer of the lower story his walls or foundation, he cannot require contribution from his subjacent or superjacent neighbor, although the latter benefitted. Loring v. Bacon; Ottumwa Lodge v. Lewis, both supra. Without such rights, the upper owner's tenure must be defeated by the destruction of the building. 
In Hahn v. Baker Lodge 21 there was a grant of a certain specified room in a building, without any stipulations as to rebuilding in case of fire or other casualty. The building burned. The court said:

"... the defendant did not acquire anj right of ormership in the building or any part of it, but in the room or space inclosed by that part of the building which was described and identified as the middle room or hall of the upper story. This it owned. But when the fire destroyed the building. . ... there was nothing remaining upon which the defendant's conveyance could operate and its rights at once terminated." $2 \pi$

Here the court distinguished the space occupied by the room from the structure which was the room, and held that the right of ownership had as its point of reference the space inclosed by the walls, and not the walls themselves. Nevertheless, it followed the rule, which it quoted from other cases, 23 that the destruction of the physical premises was also a destruction of the fee. This was upon the theory, not that the estate was in the structure which was destroyed, but that it was defeasible when the space could no longer be identified by the same physical bounds which first defined it. The result practically may be commendable, but it is not logically necessary. Be that as it may, we have in the language of the court a judicial recognition of the possibility of vertical division. As long as the structure remained, the defendant owned a bit of space called a room which is not to be confused with the physical structure surrounding it. His ownership was of fee dignity, although subject to untimely dissolution. For the time being he was the owner of a portion of cubic space, shaped like a child's block, intangible and impermanent as a mirage.

The Canadian Supreme Court had considerable difficulty when confronted with deciding just what was acquired by the adverse possession of a second story room, a shop partly below the room, and the land which went with the store.24 The adverse possession had continued for more than the limitations period, twelve years, but for a shorter time than the prescriptive period, twenty years, necessary for the acquisition of an easement. The problem was not fully solved when the majority of the court decided that the adverse possession of the upper room gave a title, although two justices doubted even that conclusion.25

2121 Ore. 30, 27 Pac. 166 (1891).

22 Ibid. 33, 27 Pac. at 167.

23 From Thorn $\nabla$. Wilson, supra note 20.

24 Iredale v. Loudon, 40 Can. Sup. Ct. 313 (1908).

25 In the Court of Appeal (the intermediate court) Garrow, J.A., believed that the statute of limitations referring to adverse possession did 
The upper room was only partly supported by the shop below, which had also been occupied by the adverse possessor. Should the owner, who of course retained his title to the rest of the building, decide to tear it down, the upper room would dangle precariously and in all probability suffer eventual destruction. Mr. Justice Duff, with the concurrence of Chief Justice Fitzpatrick, argued that a possessory title gave none of the incidents of a title obtained by grant, and hence that the adverse possessor in the instant case could demand no support from him whom he had disseized. Such a right of support might be acquired as a positive easement after occupancy for the prescriptive, as opposed to the limitations, period.

Mr. Justice Davies would not subscribe to this diminution of the adverse possessor's rights. He considered that the title acquired was of the space and not of the structure, saying:

"I did not understand it to be contended that a valid grant could not be made of an upper room or flat in a building which would give the grantee such a right as amounted to owmership of the space within the room or flat or part of the building granted, with, as against the grantor, a right of support and a necessary right of passage to the premises." 20

He believed that it logically followed that the right of support was a "proprietary right passing with the premises acquired by possession, essential to its existence and inseparable from it." ${ }^{27}$ In using the phrase, "essential to its existence," he im-

not apply, since any right acquired would "of necessity" be impermanent, and the statute comprehended only permanent properties. His argument as to the impermanency of the room was predicated upon the certainty ho felt that the right of support was such a positive easement as would havo to be acquired by virtue of a claim enduring for the prescriptive rathor than the limitations period. Maclaren, J.A., felt the same way about the easement of support. Moss, C.J.O., concurred in holding the statute of limitations inapplicable, arguing: ". . . a naked grant of an estate in freehold in an upper room does not carry with it an interest in the subjacent soil so as to make the grant savour of the permanence of realty." Ho was also of the opinion that the acts of the claimant were not sufficient to meet the requirements of adverse possession. 15 Ont. L. R. 286 (1907).

20 Iredale v. Loudon, supra note 24 , at 317. .

${ }^{27}$ The learned justice here suggests a problem which may be analyzed as follows: With ownership are normally associated a number of othor rights, such as the right to immediate possession, and the right to lateral support. Ownership as a right is thus usually but a part of a complex or bundle. The owner-the dominus of the claim to the ultimate possession-may divest himself one by one of many-of these incidental rights. For example, he can give a lease for years, and thus create in anothor the right to immediate possession. MIr. Justice Davies suggests that thoro are certain minima beyond which this process cannot go, and that the right to vertical support must necessarily accompany the right of ownership to an upper chamber. It is an indivisible complex with which we then 
plied that the right of ownership, although of the space and not of the structure alone, was defeasible by the destruction of the building, as was held in the Hahn case.28

We come now to a group of cases which are most easily explained by assuming a stratification of the landspace.

In Corbett v. Hill, ${ }^{23}$ two contiguous properties in London had been deeded separately by the man who then owned both of them. To the defendant he conveyed number thirty-four Eastcheap "as the same were then in the occupation of Joseph Prince." To the plaintiff he conveyed number fifteen Philpot Iane. Plans of the ground floor wele drawn in the margin of both conveyances. In 1866, the defendant started to pull down his building and discovered that a room on the first floor (first above the ground floor) of number fifteen Philpot Lane projected into and was supported by, his house. No projections were shown by the ground floor plans in the margins of the deeds.

The defendant, on rebuilding, manifested an intention of building over the roof of the projecting room. The plaintiff then sought an injunction on the basis of a continuing trespass, claiming the column of airspace above the projection. The defendant contended that the grant, by referring to the plat of the ground floor, impliedly gave him all above and all below the surface of the ground floor area conveyed him. He involsed the maxim, cujus est solum, ejus est usque ad coelum. If his contention had been wholly sustained, the plaintiff could have claimed no

deal. It might be suggested, as an answer to any such belief, that in mining law it has been held that the owner of the surface may divest himself entirelyi of the right to vertical support as against the owner of a subjacent mineral stratum, so that the surface may be let down to an extent that results in complete destruction of its economic value. Rorybotham v. Wilson, 8 H. L. G. 348 (1860); Duke of Buccleuch v. Wakefield, I. R. 4 H. I. 377 (1870); Penman 7. Jones, 256 Pas 416, 100 Atl. 1048 (1917). But cf. Hilton จ. Granville, I. R. 5 Q. B. 701 (1815).

In the trial court IIr. Jastice IIabee had granted an injunction against the one seeking to tear away the support. His argament was this: "I think any act of the defendants that interferes with the right of possession and enjoyment by the plaintiff of the premises now occupied by him would be a trespass." His opinion may be found in 14 Ont. I. R. 17, 21 (I906).

An unnamed author criticized this case in a Canadian legal periodical under the caption Castles in the Air. (1908) 44 CAr. L. J. 593, 597. (The phrase had been used by Mraclaren, J.A., in the court of appeal.) The critic said: "The only reasonable inference appears to be, not that an upper chamber is per se land, but that its connection with the soil makes it in contemplation of law a part of that particular piece of land over which it is erected." To one; believing that, it would be impossible, of course, to consider space as ever susceptible of ownership in horizontal strata.

${ }^{28}$ Supra note 21.

29 L. R. 9 Eq. 671. (1870). 
rights because of the projection of his room, and probably he could not even have maintained that projection. The ViceChancellor, however, argued that the maxim states only a rebuttable presumption, and that, if the intent is clear, titles may be created which carry no such implications. ${ }^{30}$ Admitting that ownership by the plaintiff of the projecting room was not precluded by any rule of law, the Vice-Chancellor proceeded:

"The question then arises, whether the protrusion is a diminution of so much of the freehold, including the right upwards and downwards, as is defined horizontally by a section of the protrusion; or whether such a portion only is carved out of the freehold as is included between the ceiling of the room at the top and the floor at the bottom.

"In my opinion the protruding room here effects only a diminution of the last-mentioned limited character. The diminution does not extend beyond the protrusion itself, which the plaintiff has, of course, retained as part of his freehold." 32

\section{This is his final conclusion as to the rights of the parties:}

"... subject to the exception which has been obtained or made by reason of the protrusion, the owner of the house in Eastcheap still remains the owner of everything else, including the column

so That the maxim when applied at common law states only a rebuttable presumption has been frequently pointed out. Hazeltine says:

"We may, if we wish, look upon this maxim as amounting, after all, to a presumption that the landowner's right is of such indefinite scope; this presumption admitting of rebuttal on proof that some other man owns a stratum below the surface or above the surface. This view, therefore, really comes only to this, that the landowner's right includes in all cases the entire subsoil and the entire air-space unless he has sold or leased a stratum of soil or air-space to somebody else." HAZELTINE, LAW OF THE AIR (1911) 75.

In discussing this phase of the Corbett case, counsel referred to such earlier decisions as Freeland v. Burt, supra note 16 , where a conveyance of a shop was held not to pass title to a cellar beneath, which had been separately demised; and Press v. Parker, 2 Bing. 456 (1825), where a demise of all of a messuage "now in the occupancy of II." was held not to preclude the giving of evidence that a cellar below had been used in connection with an adjoining messuage, and passed with the latter and not the former. In both cases the language of the conveyance implied such a limitation of the vertical extent of the subject of the conveyance as to result in a division of what would have been normally conveyed as a unit.

Counsel for the successful party also cited Kerslake v. White, 2 Stark. 508 (1819), where, in holding that a demise of a messuage included only the rooms occupied together at one and the same time, Abbott, L.C.J., said: "It frequently happens that a room of one house extends over part of a room belonging to another's house." Ibid. 509.

8z Corbett v. Fill, supra note 29 , at 673 . 
of air above the room upon which the supposed trespass has been made." 32

He therefore dismissed the bill.

The statements that the projecting room was "carved out of the freehold" of the defendant, and that the column of air above it still "remained in the ownership" of the defendant, would seem to demonstrate that the Vice-Chancellor identified the landspace as a part of the freehold, and admitted that it could be the subject of ownership. ${ }^{33}$ As a consequence of these views, he in effect recognized that here a vertically limited portion of the space was the subject of an ownership distinct from that of the space above and below it.ss

32 Ibid. 674.

ss The syllabus is in part: "Held, that the vertical column of air over so much of the room as overhung the defendant's site belonged, not to the plaintiff, but to the defendant."

sk Corbett $v$. Hill was approved twenty-two years later in Laybourn v. Gridley, [1892] 2 Ch. 53, but the result was not followed. Overhung premises had been conveyed by reference to a ground plan, without other description. It was held by the court that the overhanging part of the adjoining premises also passed. As IIr. Justice North said: "What is conveyed is the piece of land coloured green, with all the buildings thereon; that, in the absence of anything else to the contrary, passes everything above and below." Ibid. 58 [italics ours].

The learned justice went on further to clarify Corbett $\nabla$. Hill: "The defendants claimed not merely the loft as it existed, but they claimed a right to the space over it. They have pulled the loft down and substituted a new building which ... extends higher up. In my opinion, even if the defendants were right as to the ownership of the loft, it rould not make them owners of the space overhead. Upon that point I think the case of Corbett $\nabla$. Hill is conclusive." Ibid. 59. This dictum suggests that where a situation arises governed by Corbett $\nabla$. Hill, the projecting room may be torn down and another bnilt in its place provided it occupies no more space than the original projection.

Corbett v. Hill was again referred to in Newton v. Huggins \& Co., 50 Sol. J. 617 (1906). The plaintiff was the fee owner of four dwelling rooms built over an archway. He claimed that the wall of the defendant's adjoining house, which was also one side of the archway, was a party wall. Neville, J., held that it was a party wall only to the extent of the rooms above the archway, but not below the rooms. He said, at 617: "Corbett $v$. Hill shewed that when other property was interposed the right to the solum was limited to the extent to which the premises protrude; therefore plaintiff's rights were confined."

In Ranchod Shamji v. Abdulabhai IIithabhai, 28 Ind. I. R. Bomb. 428 (1904), the plaintiff asked for a mandatory injunction for the removal of a superstructure built over certain of the plaintiff's beams which had been projected over the defendant's land. It rias denied on the anthority of Corbett V. Hill.

In Potts v. Bovine, 16 Ont, Rep. 152 (1888), a testatrix had owned two buildings, with a lane or gangway between. One was built so that the second story extended over the lane. The other, together with the surface of the soil over which the lane ran, was derised to the plaintiff sabject 
A few years later, the Court of Chancery Appeals was confronted, in Reilly $v$. Booth, ${ }^{35}$ with a slightly different situation. A covered passage or gateway led through a house from a street to a garden behind the house. The premises in the rear were conveyed "together with the exclusive use of the gateway." There were rooms above the way, and a vault beneath, not granted. Genexal Booth, the grantee, and his Salvation Army then proceeded to fill its walls with prints, and to place chairs and tables in it. The grantor sought to restrain this use as inconsistent with a grant only of an easement or way. The comments of the judges on this argument, it is submitted, are inexplicable unless we accept the hypothesis with which this discussion is concerned. Lord Justice Lopes remarked that "ownership (not an easement) passed," since "there is no easement known to law that gives exclusive and unrestricted use of a piece of land." Lord Justice Cotton compared the grant to that of a set of chambers, and called it a "conveyance of the property in the passage." Lord Justice Findley agreed, but added that the grantor of the gateway "was reserving to himself that which was above it and was reserving to himself that which was below it," together: with a right of support in the rooms above the gateway, and that the grant was different in its vertical limitation from the grant of the yard in the rear. The syllabus of the case in the Law Reports contains the note that apparently "such a right amounted to the ownership of the space within the gateway." This view of the case seems in harmony both with the result and with the ratio decidendi.

The court does not say anything concerming its attitude had the passage and its adjuncts been destroyed. General Booth had contracted for'more than a mere right of way; he had contracted for the property in the space used for the way. It is consistent with the logic of the case and with the genius of the law to believe that the destruction of the building through which the passage had been run would not terminate or diminish his rights. ${ }^{30}$

Three cases decided by courts of last resort in this country

to a right of ingress and egress by the defendant, the devisee of the building of which the extending rooms were a part. The plaintiff sought by this action to get the possession of the rooms over the lane on the theory that the land, having been devised to him, included all above it. His action was refused, GaIt, G.J., holding the presumption rebutted by the facts in the case. Press v. Parker, supra note 30 ; Freeland v. Burt, supra note 16; and Corbett v. Hill, supra note 29, were cited.

35 44. Ch. D. 12 (1890).

${ }^{30}$ An interesting comparison can be made with Riley v. Pearson, 120 Minn. 210, 139 N. W. 361 (1913), where a perpetual easement to an arched passage was held to survive the destruction of the building through which the passage ran. 
are of great value to an understanding of our proposition. In the first, Weaver $v$. Osborne, ${ }^{37}$ the defendant's predecessor in title owned a two story frame building and the lot on which it was situated. In 1893, he granted to the plaintiffs property described as: "All the second story of my store building, commencing thirteen feet from the foundation, ... size of building twenty-two by fifty feet." The-description was followed by mutual covenants to maintain and repair the respective stories, with mutual rights given each to demand that the other repair his portion. This sentence followed: "In case of fire, let it be optional with either party in case of building." The entire building was destroyed by fire in 1909. The defendant then began to erect another store building on the site of the one destroyed, but denied the plaintiffs the right to rebuild the second story. The plaintiffs asked a decree confirming their right to erect, have, and use a second story on the building begun by the defendant. 'On demurrer, the bill was dismissed by the court below.

On appeal, the court first expressed the belief that, in the absence of any covenants or language in the conveyances indicating a different intent, title to an upper story is "title to the second story then in existence," and ceases with the destruction of the building "by fire or otherwise." Justice Weaver, writing the opinion, suggested that in the cases which so intimate we find qualifications such as "in the absence of contract," so that, despite the holdings, we may infer that parties have the power when exercised to create rights which will survive destruction. ${ }^{33}$ He construed the clause beginning "In case of fire" as an expression of such an intention. Neither party was given the right to compel the other to rebuild, but in case either chose to do so the other had the "option" to rebuild his part. Practically, that put the first election solely up to the lower proprietor, for

37 Supra note 20.

38 The cases he particularly cited were: Jackson v. Bruns; Pierce v. Dyer, both supra note 20; Association v. Hegele, 24 Ore. 16, 32 Pac. 679 (1893). Association v. Hegele involved a party wall agreement to which the court denied effect after the servient building had been torn down; it does not bear on our problem, and was cited only for the analogy which seemed to the court to exist. Pierce $\nabla$. Dyer was also a party-wall case, but the opinion contains this general language, when spealing of mutual rights of support: "When thus destroyed, it is fair to presume that the parties intend, in the absence of any agrement, that the easoment shall end with the necessity which created it." 109 Jiass. at 377. Jackson $\nabla$. Bruns is the only one of the three cases which deals with an actual instance of story ownership. In it we find the following language: "If the defendant, does not desire to restore his walls to a sound and safe condition for his own benefit, he ought not to be compelled to maintain them for the benefit of plaintiff, in the absence of aray express or implicd contract on his part." 129 Iova at $623,106 \mathrm{~N}$. W. at 3. [Italice ours] 
he alone could build without his neighbor. Since in the present case the lower proprietor had started rebuilding, his superjacent neighbor could demand the right to rebuild the second.story. The case was reversed.

The defendant's new building was of slightly different dimensions than the old, its length being greater. The court, however, limited the new second story to the dimensions set out in the conveyance. Does not this, as well as the general result, lead us to the belief that the conveyance was of the title to a portion of space twenty-two by fifty feet in lateral extent, beginning thirteen feet above the foundations of the old building and extending upward, either to the height of the old second story, or indefinitely further? ${ }^{30}$

That the landspace was divided by a horizontal plane thirteen

so The author of the note to this case in (1913) 38 I. R. A. (N. G.) 706, found no parallel cases, but approved the decision.

In the conveyance involved in the two cases entitled McConnel v. Iribbe, supra notes 19 and 20, there was the following provision: "McConnel to have, use, and occupy the said buildings above the first story aforesaid forever, and in case of the destruction of the said buildings or either of them, said McConnel to have the right to make and continue up walls upon walls which may be made for any new building to any height consistent with safety of the building." .This provision apparently never camo to an appellate court for construction, but it shows that such a situation as that which caused the litigation in Weaver v. Osborne may occur moro than once.

Our hypothesis concerning the result of Weaver v. Osborne suggests some interesting problems:

I. If the conveyance passed title to an upper stratum of space, and that title was not defeated by the destruction of the building, it is logical to believe that any use of the land by the lower owner, other than such a rebuilding as gave the plaintiffs the right to demand support for a now second story which would have resulted in a projection more than thirteen feet above the surface, "would have been a trespass on the plaintiff's domain.

2. Suppose the defendants had not elected to rebuild, would the plaintiffs' title ever be lost? Possibly the court might hold that possession of the surface by the defendants would, by a constructive adverse possession, eventually reunite the titles after the limitations period, since it would hardly be possible for the plaintiffs to assert their possession of this unattainable and intangible property. This result would be opposed, however, to the Scots decision, Urquhart $v$. Marshall, infra note 60 , and possibly to the general rule that possession of the surface does not constitute adverse possession of separately owned unworked minerals below.

The property in space has little or no economic value under present conditions until the election of the lower owner to rebuild. This emphasizes the importance of the right to require support for a structure, enabling use of the property to be made. In fact, as may be implied' from much of the argument in Iredale v. Loudoun, supra note 24, the rule that titlo to an upper story is ordinarily defeated by destruction of the building really rests upon the practical consideration that the right to support is lost and the property has no economic value. It is a pragmatic, not a logical, rule. 
feet above the soil is at most only an inference to be drawn from the legal effect of the conveyance involved in Weaver v. Osborne. Pearson v. Matheson ${ }^{10}$ is a parallel case in which it was expressly recognized that the upper owner had a title to the space itself which would survive destruction of the original building. The conveyance was of an undeveloped block, with a contemporaneous contract made a part of it whereby the grantee was to erect a one story store-room not over fourteen feet in height and the grantor was to erect a hotel over the store-room. In case of fire, provision, was made for rebuilding within twelve months, the expenses to be pro-rated. The grantor and grantee later entered into a separate contract by which a skylight was provided for the benefit of the grantee. The grantee subsequently conveyed the lot and store; a fire followed; and a dispute arose when the rebuilding was planned.

It was argued that the deed and the first contract, which had been made a part of it, were repugnant, and hence that the contract permitting the erection of the hotel was void. MIr. Justice Gage said:

"The two together plainly evince the intent of the parties to confine Watson's [the grantee's] tenure to the soil of the lot granted and fourteen feet above it; and to reserve to ilatheson [the grantor] the use of all that space which lay above the fourteen foot line parallel to and above the soil. The only issue, if there be any issue, is whether such a contract may be made." si

On the analogy of grants of mines and the like, the justice held that a conveyance of what he called "that aerial part of the lot lying above a line parallel to the earth and fourteen feet above the earth" could be made. Consequently there was no repugnance between the deed and the first contract.

Attention then centered on the later contract for a skylight. The Justice pointed out that:

"So far as the deed and concurrent contract show, a solid floor and rooms on it may have been constructed immediately above Pearson's store, and in that event a skylight would not have been possible of construction." 12

But Matheson accepted a valuable consideration from Watson, and agreed with him and his assigns to permit the skylight in the existing building or in others replacing it. The court held that the right created survived both Watson's death and the

to 102 S. C. 377,86 S. F. 1063 (1915). Althorigh the case was decided after Weaver $\nabla$. Osborne, supra note 20 , the Iowa decision apparently was not called to the attention of the court.

4I Ibid. 382, 86 S. E. at 1064.

12 Ibid. 382-383, 86 S. E. at 1065. 
destruction of the building, adding: "If Watson's right must have a name, then it was an easement in Matheson's dominion of the air over the fourteen foot line." ,

Here is an indisputable instance of such a stratification of the landspace as we have been seeking. ${ }^{43}$ As it was' phrased in the opinion of the court, "Matheson was sovereign of the air over the Watson store which lay above the fourteen foot line." His right was independent of the existence of any structure occupying the space which belonged to him.

One further point of interest should be noted. Unlilke the conveyances which have been the basis of the other cases, the one here was made before any building had been erected to identify the aexial lot. The lot was described by its relation to the surface of the soil and not by its relation to something man-made.44

43 This is the interpretation which others have given this decision. A note to this case, entitled The Air Space as Corporeal Realty in (1916) 29 HARv. L. REv. 525, after citing examples of the separate ormership of chambers, stated the problem in this wise:

"When a building thus owned is destroyed, a question arises whether an owner of a portion of it who had no rights in the soil can claim the space formexly occupied by his property. . . . An estate in fee may also be intended to embrace only a portion of the building, itself and not the space it occupies; but the question still remains whether ownership of - unattached air space is possible where a clear attempt is made to creato it." Ibid. 525.

The commentator believed that Pearson v. Matheson, supra note 40, answered the question in the affirmative. Tiffany is of the same opinion, for he says (speaking of the separate ownership of chambers):

"Whether the owner of land, in the ordinary case, actually owns tho air space above the land, and whether such air space is susceptible of division into strata for the purpose of separate ownership, is a question of difficulty. That it is so divisible appears to have been decided in one case" (referring ta Pearson v. Matheson). 1 TIFFANY; op. cit. supra noto 6 , at $865, \S 251$.

st The facts of Pearson v. Matheson, supra note 40,--the erection of a hotel by one party above a building belonging to another-make relovant mention of what has been called "Cleveland's sks lease." MoMrorrar, LONG TERM LAND LEASEHOLDS (1921) 19 et seq. One Brown built a fivo story building on a frontage leased for a long term. He leased to tho Cleveland Athletic Club for ninety-nine years the space above his building, granting easements of access through stairways and elevators. The Club thereupon erected an eight story building on top of Brown's structure. The club pays taxes on its portion of the building, but has no ground taxes to meet. At the end of the ninety-nine years of the lease from Brown, the latter, his assigns or successors, must pay the club or its successors the appraised value of the club's portion of the building as it then exists and adds to the value of the land. The owners of the reversion to the land have joined in the lease so as to guarantee Brown's performance. The nature of the lease is apparent from a reading of it, especially the granting clause, which is in part as follows:

"Whereas, the Lessee desires to acquire the right to construct and maintain upon said building now in course of erection by said Lessor and upon 
The Pearson case was cited a few years later in Taft v. Washington MIvtual Savings Bank, st a Washington case. Under a statute of the state, property held in fee by a city reverted to the abutting property owners when vacated. Another statute authorized the vacation of a street or alley or any part thereof without limitation. A municipal corporation owned the fee to an alley. Property owners on both sides of a portion of the alley wished to erect a building extending in its upper stories. over the alley. To enable this to be done, the municipality by ordinance vacated that portion of the alley which extended in. definitely upward from a horizontal plane sixteen feet above the surface of the alley. Other property owners along the alley objected when the building was commenced, but the procedure was upheld on appeal. Mr. Justice Holcomb first suggested that. the municipality owned the space vacated; then, referring to the Pearson case, he concluded that the landspace thus owned could be divided, as had in effect been done, by the municipality.

\section{III}

The recognition by the common law of fees in chambers and stories leads us to inquire whether the growing practice in the larger cities of "selling" apartments in so-called co-operativebuildings depends upon such a principle of law. In popular

any other building which may hereafter be constructed or erected upon said premises additional stories and improvements, together with the right of suitable access thereto . . ." The lease is set out in IICLIrCEnEr, op. cit. supra at 158-170.

When lawyers are drafting instruments such as these, when situations are arising which require leases of this sort, when the right to build many stories becomes valuable bejond what was considered possible a few years ago, it seems inevitable that the courts will be confronted in a practical form with the question which has been more or less acrdemically discussed. in this paper.

The taxation feature of the Cleveland "sky lease" is reminiscent of the case of Cincinnati College v. Yeatman, $30 \mathrm{Oh}$. St. 276 (1876), where there was a lease of apartments occupying the front of a second story for ten thousand years renewable forever, the lessor to rebuild as before in case of fire with the same rights in the lessee. The court granted a mandamus on the suit of the lessor compelling the separate taration of the apartments as distinct property, because there was an Ohio statute maling long term leaseholds governable by the same rules of lav as if they were fees.

45 127 Wash. 503, 221 Pac. 604 (1923).

so It has been pointed out that this procedure could not be followed in other jurisdictions because of the rights in the remaining owners along the street or alley to light and air as well as passage which those jurisdictions recognize. Bell, Air Rights (1928) 23 IIL. I. REv. 250, 256. This consideration does not destroy or impair the value of the Washington decision as an authority in support of the right to divide land into horizontal strata. 
discussion, in the talk of real estate salesmen, and in the minds of the dwellers therein, these apartments are frequently, if not usually, treated as separate properties. In this lies their sales value; they are a satisfaction of the desire to be a freeholder and not a tenant, which is our inheritance from a society differently circumstanced. It is a desire difficult of fruition when cities have so grown that we must build many feet slkyward in order to utilize the full value which we conceive aur lands to possess. Yet, oddly enough, the cooperatives, while attaining the practical result, do so by the use of a legal device which directly negatives ownership. The reasons for this have been concisely indicated by Mr. Castle; who has written the only adequate discussion of them from the strictly legal viewpoint:

"The idea of describing real property for purposes of conveyance as a certain room or rooms in a building may be comparatively unfamiliar, but there is nothing theoretically impossible about it. However, the ends . . . could be attained, if at all, only by a complicated series of agreements, uncertain in operation and lacking in 'teeth.' Each apartment owner, would, among other things, be confronted with the practical difficulty, if not impossibility, of arranging to have his individual apartment insured separately and assessed separately for taxation." "

The same writer then points out the practical difficulties of any arrangement in the nature of a joint tenancy. He finally concludes:

"The objective can be attained, therefore, only by providing some agency which will serve as a repository for the entire legal title, and which will issue to the apartment purchasers appropriate instruments evidencing their respective rights and interests in the property and binding them by the act of acceptance to the obligations already mentioned." 18

According to Mr. Castle, only two such forms of organization, which he calls the "corporation plan" and the "trust plan," have been found reasonably adequate. In the first, a corporation, of whatever sort is permitted under the statutes of the state to own real estate and build thereon, is created with the prospective owners as stockholders. The corporation takes the title to the land, handles the financing (by mortgage or trust deed), and gives to each "owner" a "proprietary lease" of that apartment

"Castle, Leigal Phases ofi Co-operative Buildings (1928) 2 So. CalrF. REv. 3.

A description is to be found in ClaAR, Cooperative Apartinent Houses AS AN INvESTMENT (Northwestern Univ. School of Commerce, 1924) 14-15. Mr. Claar is also the author of the chapter on these buildings in MLACChesneY, ReaL Estate LaW (1927) Ch. VIII.

48 Castle, loc. cit. suprai note 47. 
which is to be his. In the second, a similar result is achieved with the substitution of trustee's certificates for share certificates.

Both plans are adaptations of our legal mechanism to a novel situation. Complexities always result from such adaptations, and this instance is no exception. The "proprietary" leases are exceptionally long-winded instruments, quite terrifying at times to the layman.19 Despite this difficulty, the co-operatives seem to be increasing in favour and multiplying in number. Simplification will be the inevitable result.

While we find here no apparent encouragement for our proposition that the landspace can be stratified, and the resulting divisions separately owned, the phenomenon of the cooperative apartment has this important consequence: Just as the willingness of the courts to admit that a chamber could be separately conveyed resulted from the accustoming of the judges to the notion by the practical examples surrounding them in the Inns of Court, so will our courts of tomorrow cease to regard as strange the ownership of castles in the air many stories above the streets. Mr. Castle regards the right of the dweller in these apartments as "practical ownership" (whatever that is), and cites an opinion of the Attorney-General of Mlinnesota to show

19 See Castle, op. cit. supra note 47. A number of forms, from New York, Chicago, and Califormia, are set out in CUTLER's TIFraNY's Fors Book (Cutler's 2d ed. 1927) 567 et seg. Several matters which appear therein have a particular interest for us. Thus, in the proprietary lease given as a New York form we find that it is provided that the lease shall cease in case of the total destruction of the building by fire, " . . . unless the insurer shall elect to rebuild same building under the terms of any provisions which may be contained in their policies of insurance, in which case this lease shall not terminate but shall continue and apply in respect to the premises in said building so rebuilt, which shall correspond with the premises hereby demised." Ibid. 573. A similar provision is contained in the Chicago form. Ibid. 586.

In the California forms, which provide for a trustee as the eventual repository of title, there is a provision that there shall be issued: " ... a certificate of beneficial ownership under said trust, issued by said trustee, showing the buyer's undivided fractional beneficial interest in the building and real property as a whole, and his exclusive right of occupancy under the trust of the said apartment hereinabove designated." Ibid. 597. Occasionally the language goes further: "The buyer . . . agrees to purchsse apartment no. ...... on the ...... floor of said proposed building, as designated on the floor plan of said proposed building , ..."

Speaking of these arrangements, it has been said: "The purchaser of a co-operative apartment buys shares of stock in the corporation to an amount equal to the equity covering the apartment he has selected. Actually he buys developed air-rights when he buys an apartment." Burritt, From the Ground Up (1928) 54 IIAG. OF BUS. 39. This is the inevitable reaction of the Iagman. 
that he has companions in his belief. Thus is the ground prepared for seed perhaps already sown.

IV

Separate ownership of chambers, such as the common law permits, finds few counterparts in those countries where the civil law governs. The Roman system has always been firmly wedded to the belief that where nature has indicated unity the law should not countenance division. The column of landspace has seemed to the Roman lawyer to possess the indicia of unity, and the two familiar maxims of land law, superficies solo cedit, and cujus est solum, ejus est usque ad coelum, have found unqualified acceptance by civil lawyers..$^{50}$

In Germany, however, the Roman law has not always been predominant. The old Germanic conceptions were more alkin to the spirit of the common law, and many times were incompatible with the alien notions introduced by the Reception. From the 1100 's on story or roomage ownership was widespread. Huebner describes it as follows:

"Houses were horizontally divided, and the specific parts so created-the stories, floors, and cellars-were held by different persons in separate ownership; this being associated, as a rule, with community ownership of the building site and the portions of the building (walls, stairs, roof, etc.) that were used in common." m

The tenacity of the institution is indicated by its survival after the Reception in many localities. Huebner cites as an example a contract drawn in 1901 between a municipality and a cathedial building endowment. The enabling act of the German Civil Code expressly recognized continuance of property in building-stories existing at the time the Code became effective. ${ }^{52}$ The institution flourished in Switzerland, and the same attitude toward it was taken by the Swiss Civil Code.53

Property in stories and in parts of stories has been commonly recognized by the Scottish courts, although the system they administer is of Roman origin. A considerable body of law has been evolved. The origin of the rules does not clearly appear.

${ }^{30}$ See Hazeinine, op. cit. supra note 30, at 74-75: " . . . the Roman law permitting no ownership in limited stratum of soil or airspace, but allowing only the landowner's full dominium or ownership to be encumbered by certain rights less than ownership."

or HUEBNer, op. cit. supra note 8 , at 174 ; of. SCHUSTER, PRINChples of GRRMANIC CTVII LAW (1907) 413, \& 349.

52 GERMIAN CrVIL CODE (1900) \& 128.

53 SwISS Crvm Code (1907) § 675.2. 
Several cases have a particular interest for us, both because they throw light upon the nature of the property and because they foreshadow situations which may some day come before our own courts.

In Dennistoun v. Bell, ses decided by the Court of Session in 1824, the respondent sought to convert the under floors of a tenement into shops. The advocator, who owned an upper floor, resisted the application made by the respondent to the Dean of Guild for authority to make the alteration on two grounds: (1) The alterations were of such a nature as to create a reasonable degree of alarm for the safety of the upper floors. (2) The upper' owner's consent was necessary because his right in the inferior part of the tenement partook of the nature of common property. An architect reported to the court adversely to the first contention. The court adhered to the granting of the warrant, holding that the question of danger to the upper tenement was the sole one involved, thus denying that the right of the upper owner in the inferior portion of the house was more than a servitude of support.5

The facts in Stewart v. Blackwood, were somewhat different. The defender in the action was the proprietor of the second and third floors and of the garret of a building in Glasgow situated over a ground floor belonging to the pursuer. The original building was torn down in 1823 pursuant to an order of condemnation of the Dean of Guild.

5\& 2 Shaw 649 (1824).

55 Two decisions a year earlier had prepared the way. In Sandy v. Innes, 2 Shaw 195 (1823), Sandy owned an upper flat and attic. He sought to extend a common stair to the flat up to the attic, and to convert the attic into separate divellings. The original stair to the attic ran from inside the upper floor. The lower owners sought an interdict. The Court of Session, while continuing the interdict granted below, required a trial on it.

In MicKean v. Davidson, 2 Shaw 426 (1823), Davidson, the proprietor of the lower paxt of a house the upper part of which belonged to WICKean, sought to convert the sunk and first floors into shops. To do this, the front walls had to be removed and the upper wall supported by props. The Dean of Guild granted a warrant for so doing if Devidson rould find caution de damnis. To this decision the Court of Session adhered. This decision thus went further than the Sandy case, although the advocator (McKean) had relied on the Sandy case.

After Dennistoun v. Bell, supra note 54, had been decided, its principle was followed and extended in Grey v. Greig, 4 Shaw 105 (1825). This was another application to the Dean of Guild for warrant to convert sunl and street flats into shops. It was granted with a gualification that Greig should find caution de damnis, and the Court of Session adhered after a report by an architect that the alteration could be made without apparent risk. The advocatior had also raised the point of the effect on the value of her property, but the result was not changed.

587 Shaw 362 (1829). 
The litigation arose to determine the rights of the parties in the new building to be erected on the site of the old. The pursuer wanted to make a sunk story in the new building, in the part not occupied by the common passage, so as to give him both the street floor and such sunk story. He therefore raised an action of declarator of title to have it found that he was the exclusive proprietor of the "solum" or soil beneath the part of the ground floor which belonged to him. The defender pleaded that she had a real right in the "solum," and was a joint proprietor in it; and that "she was not bound in law to submit to have in the new building merely a third story, instead of a second as possessed by her in the former tenement." The Lord Ordinary sustained the defenses and granted an interlocutor.

When the case came before the Court of Session, the Lord Ordinary's interlocutor was adhered to, Lord Glenlee saying:

"The right of the proprietor of the lower flat is not a right of absolute and exclusive property in the solum, burdened with a servitude oneris ferendi; and though the solum may not be, strictly speaking, joint property, yet there is in it a joint interest sui generis, which prevents any one of the proprietors of a house from doing anything to the prejudice of the rest." ${ }^{\circ}$

Throughout the case it was assumed that in the event of such a destruction as had taken place the proprietors of the several

57 Ibid. 363. What the phrases "joint interest" and "joint property," or "common interest" and "common property" mean in these discussions is better to be understood from the language of the opinions in Gellatly v. Arrol, 1 Macph. 592 (1863), where the question was raised as to the right of the upper proprietor (the defender) to cut through his side walls to make openings into adjoining buildings. The Lord Justice-Clerk (Lord Inglis), after pointing out that each owner had a right of property in the part of the gable bounding his own property, and an interest in the rest for carrying up the vents or chimneys for his parts, said:

"It may be difficult to say what the nature of this right is, whether it is a right of common property or a common interest. I am not sure that the line between these different rights is well defined; but . . . I am inclined to lean to the opinion that it is common interest and not common property. Such was the principle in the judgment in the case of Stewart v. Blackwood." Ibid. 599.

Lord Cowan, concurring, nevertheless inclined to a different viow. Dofining the terms, he said:

"Professor Bell has stated the difference between common interest and common property to be this-that where the right is that of common interesti merely, and where no case of danger has been made out, the Courts have authorized alterations to be made; whereas if the right be ono of common property, no one can touch the subject of common property so as to innovate on its character without the consent of all the other proprietors." Ibid. 601.

The right to cut through was denied in the case, because actual dangar was shown. The other justices did not commit themselves on the naturo of the rights. 
stories had a right to the same portion of the rebuilt structure as they owned before the destruction. The decision is based on the belief that they were entitled to take their portion of the new building burdened with no greater servitudes than had attached to their portion of the old, and that the changing of the second story into a third story changed the burden of the servitudes.

The court does not clearly define the nature of the interest of the several parties in the "solum." Apparently the evidence failed to show clearly by the title deeds in whom the title to the "solum" or land itself was, whether in the pursuer or some third party. It is possible that the land was still retained by the original builder, who had conveyed away the properties in the building without mention of the "solum." ss

The decision seems reasonable if based on no other proposition than that, even if the pursuer had ormed the soil, he should not by his use of it be permitted to multiply the easements which burdened the defender's property. 50

That we are dealing with clear instances of the separation of landspace into horizontal strata seems a necessary inference from the decision in Urquhart v. Marshall.0 The title deeds to both the upper and lower tenements described them as bounded by the street in front. As originally built, they did not extend that far forward, a sunk area intervening. The lower owner first paved over the sunk area, then built out to the street, and this case arose upon an application by the upper owner for leave to extend his tenement out over this new erection. Two bases for objection to the application were upheld by the Dean of

is Erskine, the commentator, confesses to obscurity as to the import of this and the other cases dealing with the rights of the proprietors in the soil. ERsmine, Principles of The leaw of Scothand (20th ed. 1903) blo 11, tit. ix, $\$ 8$, p. 204.

so The extent to which property in a story could be used as suited the proprietor is shown by a later decision, Anderson v. Saunders, 9 Shaw 564 (1831). In 1825 Saunders purchased a shop or street story and the sunk story of a tenement. The upper three stories belonged to separate proprietors, among them being Anderson. The common stair extended to the sunk story, and to the cellars below apportioned to the various proprietors, but there was also an inside stair from the shop to the sunk story. Previous to Saunders' purchase the shop and sunk floors were occupied as one tenement. Saunders, however, let out the sunk floor as a separate dwelling, having his tenants use the outer, common stair. The proprietors of the upper stories asked for an interdict to force the use of the shop stairway by these new tenants. The Cout of Session recalled the interdict granted by the Lord Ordinary, holding that the conveyance to Saunders, which was of "all and whole the shop story and sunls story immediately below the same, etc., with the cellars below, the common stair leading to the said sunk floor, ... " permitted such a use.

${ }^{00} 16$ Dunl. 307 (1853). 
Guild but were denied on appeal both by the Lord Ordinary and by the Court of Session:

(1) The seven year's occupancy of the under shop gave a possessory title a coelo of the space in front of the upper tenement. Answering this argument, the Lord Ordinary (Lord Curriehill) said:

"The respondents, however, so far from having established exclusive possession of that space for the last seven years, have not proven, nor even alleged, a single act of possession on their part of that space within that period. On the contrary, that space appears to have been hitherto entirely vacant, excepting in so far as it has been occupied by the advocators themselves and their tenants. The advocators state, and the fact does not appear to be disputed, that for a much longer period they and their tenants have occupied a considerable portion of that space, by the windows of their shop having been made to project into it, and by a balcony belonging to them having been made to project over it .... The Dean of Guild's judgment accordingly sets forth, not that there is any evidence of such possession of this space by, the respondents, but merely that they have been in possession of it because of their possession of another space which is beneath it and adhered to their own shops. But this is not a logical inference." ${ }^{\text {61 }}$

The Lord Ordinary was sustained on this ground without the Court of Session deeming comment necessary.

(2) The objectors alleged that they were owners of the ground forming the sunk area, and as such were owners of all the vacant space perpendicularly above it. Therefore they could prohibit any intrusion into that space: The Lord Ordinary gave two answers to this: (a) The ground story which respondents owned was bounded in altitude, and this limit in altitude affected the space over the sunk area as well as that contained in the ground floor. (b) If the title of the respondents ran to the street, so also did the title of the advocators. The Lord Ordinary said :

"And it follows that if that boundary, when applied to the lower story, would import its extension over the vacant space between its side wall and Princes Street, the same boundary, when applied to the upper story, would also import its extension over the vacant space between its side wall and that street." 02

The Lord Ordinary was cautious, however, and stated that he was not deciding definitely that the space belonged to the upper owner, but only that it did not belong to the lower proprietor. This seems excessive Scots caution.

The Court. of Session also sustained the Lord Ordinary in

as Ibid. 309.

o2 Ibid. 
this division of his holding. The court must have regarded the conveyance by which the upper proprietor acquired his title as one of a horizontally defined portion of landspace some of which was not occupied by any structure. ${ }^{03}$

In Arrol v. Inches, ${ }^{\text {ss }}$ where the owner of the upper three stories of a building likewise sought to extend them over an addition built by the proprietor of the soil and first story in space formerly unoccupied between the original building and the lot line, the court held that the upper proprietor could not do so. Here the conveyance to the upper proprietor was of "storeys," without other specified boundaries. The inference is that the property of upper proprietors is strictly limited to the space occupied by the portion of the structure identifying it in the conveyance, unless there is other descriptive language, extending the boundaries of the upper stratum. ${ }^{\text {s5 }}$

The same inference may be drawn from the decision in Watt v. Burgess's Trustee. ${ }^{\text {so }}$ The owner of an attic story wanted to tear it away and build two stories in its place. His right to do so was denied, and the following arguments were advanced by Iord McLaren in support of the decision:

"s. . . the first proprietor of the undivided tenement had, together with the tenant, the right of indefinite extension of his use of this fraction of the earth's surface upwards and downwards, without any limitations except such as result from physical difficulties .... He parted with that right only to the extent, so far as the petitioner is concerned, of conveying to the pursuer's predescessor in title a stratum of ten or twelve feet in height, defined as a storey in the tenement. I am unable to find, in a conveyance so defined, any possibilities of extension against the will of the proprietor from whom the conveyance proceeds. The estate of the pursuer is merely a stratum conveyed out of the larger estate, which extends theoretically from the center of the earth upwards, and it follows in my opinion that whatever is not conveyed remains with the grantor. It is true that the grantor is not himself entitled to build above the pursuer's storey. But this disability, as it appears to me, is the result of implied contract, because a proprietor who has sold a subject described as the uppermost of a certain number of storeys could

as It was intimated by Lord Rutherfurd in the Court of Session that, before the lower owner had built, the upper owner could not have constructed overhanging balconies or done anything with his space obstructing or inconveniencing his neighbor below. This is only the recognition of easements which are reasonable and naturai in such.a situation.

64 14 Rettie 394, 24 Scot. I. R. 287 (1887).

65 Compare this case with the part of the decision in Weaver v. Osborne, supra note 20, which limited the right of the lodge trustees in rebuilding to the extent of the original upper story conveyed to them.

es 18 Rettie 766, 28 Scot. I. R. 496 (1891). 
not, without derogating from his grant, put an additional storey on to the tenement." 67

Several dicta in the case recognize that, if the building had to be rebuilt, it "must either be rebuilt according to the original design, or ... each proprietor should be entitled to duplicate his storey."

The Scottish decisions recognize that the owner of the upper story has title to the roof, so as to enable him to cut holes through it and to make other uses of it not inconsistent with the limitations of his title already suggested. ${ }^{88}$ The courts of Scot-

${ }^{87}$ Ibid. 769,28 Scot. I. R. at 499. This language is reminiscent of the passage in Corbett $\mathrm{v}$. Hill, supra note 29, which speaks of the protruding room as carved out of the freehold, and the decision accords with the dictum in Laybourn v. Gridley, supra note 34. The implied contract preventing the owner who had conveyed the uppermost story from adding another carries the logic a step further than the English cases.

o8 This is so even when the ownership of the top story is divided. Sanderson's Trustees v. Yule, 25 Rettie 211, 35 Scot. L. R. 140 (1897). This case also is interesting in its holding that the lower owners are bound to contribute to the upkeep of the roof, which seems to be contra to the American rule and the probable English rule. See supra note 20.

This rule resulted in one decision somewhat modifying the result in Watt v. Burgess's Trustee, supra note 66. In Taylor v. Dunlop, $11 \mathrm{Macph}$. 25,26 (1872), the petitioner was the ultimate grantee from the builder of "all and whole the second or upper flat of the tenement," while the respondent was the ultimate grantee of the tenement "excepting ... all and whole the second or upper flat." The roof extended from a gablo wall on one side higher than the roof of the second story, and enclosed an attic space never occupied. The petitioner sought license to run a stairway to this attic space and cut it into rooms, and also to cut skylights in the roof above. It was not disputed but that the improvements could be made without injury to the lower flat. The right of an owner to change the character of the building was recognized, as in Anderson v. Saunders, supra note 59. As to the right of the upper owner to this attic space, there was a division of the court. The majority held that the petitioner owned the roof and the space beneath it; therefore he could make any use of it he wished to make. Lord President Inglis, dissenting, said:

"The property in the roof and in everything above the jousts of the upper flat remained in Mr. Campbell (the builder). The only thing ho had given out was the second or upper flat of his tenement. Now I. do not think that it is necessary here to consider any general question of law applicable to such tenements. The whole of the case depends upon the construction of the titles, and I do not think that there is any difficulty as to the general law. If the floor here disponed had been an attic floor, there is no doubt that the roof would have been the property of the disponee, because, as Lord Deas has said, the roof would be the wall of his house; but when the disponee is not the owner of the space between the roof and the ceiling of his house, what right of property can he have in the roof itself?"

He pointed to the conveyances and also to the fact that the maintenance and upholding of the roof was exṕressly cast upon the petitioner, whereas 
land have passed on the rights of story proprietors in a number of other cases, which deal mostly with rights in areas, staircases, and other appurtenances of the building, and have no direct importance in this inquiry..$^{\circ 0}$

France likewise seems to have relaxed the severity of the Roman presumptions. The French Civil Code by implication permits the ownership of stories or rooms. Article 553, which follows the codification of the maxim cujus est solum, ejus est vsque od coelum in Article 552, provides that all buildings or other structures shall be presumed to have been built by the owner of the soil, and to belong to him, "if the contrary be not proven." 70 The rebuttability of the presumption implies the possibility of separate and divided ownership in erections, and the law is so understood. As one French commentator phrases it, ". . . the different stories of one house can belong to different persons." " 1 Story ownership can be created either by contract or by adverse possession.72

One who thus owns a building or part of a building on the land of another is known as a superficiaire, and the right by which he holds it the droit de superficie. ${ }^{73}$ This is an adaptation

at common law if it had been his he would have been so bound angray. This dissent commends itself as the sounder view.

e9 Graham V. Greig, 1 Dunl. 171 (1838); Johnston v. White, 4 Rettie 721, 14 Scot. I. R. 472 (1877); Barclay v. IreEven, 7 Rettie 792, 17 Scot. I. R. 558 (1880) ; Boswell v. Magistrates of Edinburgh, 8 Rettie 986, 18 Scot. I. R. 708 (1881); Sutherland v. Barbour, 15 Rettie 62 (1887); Todd v. Wilson, 22 Rettie 172, 32 Scot. I. R. 112 (1894).

${ }^{20}$ "Toutes constructions, plantations, et ouvrages sur un terrain ou dans l'intérieur sont présumés faits par le propriétaire, à ses frais, et lui appartenir, si le contraive n'est pas prouvé." FreNCH Crvn CODE (1803) art. 553.

71 "Les divers étages d'une maison peuvent appartenir il des personnes différentes." BAUDRY-IACANTnNerIE, DES BIENS § 201. The remarl: is made in the course of a discussion of joint ornership, for the purpose of showing that all cases where property in a thing is divided between many are not instances of co-proprietorship. Emphasizing this, the author adds:

'Nous avons, non plusieurs copropriétaires, ayant sur la chose un droit de même nature, mais bien plusieurs propriétaires ayant des droits différents, et par suite aucun ne peut demander le partage, ì la différence de ce qui a lieu entre copropriétaires." This is reminiscent of the common law decisions denying the right to partition, cited supra note 19.

72 Article 553 itself adds to the portion already quoted: ". . sans préjudice de la propriété qu'un tiers pourrait avoir acquise, ou pourrait acquérir par prescription, soit d'un souterrain sous le bâtiment d'sutrni, soit de toute autre partie du bâtiment."

The extent of the right in a particular case is therefore affected by the terms of the contract creating it, or by the conditions under which it was acquired by prescription. 1 Dentolonibe, TRATTÉ de LA DISTINCTION DES BIENS (1861) § 483 quater, p. 396.

${ }^{3}$ 'Lorsqu'une personne est propriëtaire du tréfonds, tandis qu'une autre 
of terms employed in the Roman law, which, while not admitting of any exception to the presumption of complete vertical ownership, did recognize a jus in re aliena known as superficies. This was akin to a Iong-term lease of building land upon payment of an annual rent, sometimes in perpetuity. On this land the superficiary (superficiarius) built a house with his own materials and occupied it. While title to the building passed to the owner of the soil because superficies solo cedit, the superficiary had a real right which passed to his heirs and gave him legal possession. It still remained, however, a jus in re aliena."4

The French law has retained the Roman law terms, but has vastly changed the legal concept. While the Code provisions imply that the right exists, nothing is said about the nature of the right. In consequence there is confusion and argument among the commentators. Planiol says, frankly, that "the nature of the right is debated even today." 75 Demolombe adds that it is regrettable that the Code did not precisely delimit the character and effects of the right. ${ }^{\circ}$ A few students, influenced by the Roman law, consider it to be no more than a jus in re aliena, but the majority of textwriters are agreed that it is a jus ini re propria, or right of property. Thus even Planiol, more uncertain than many of the others, speaks of it as un droit de proprieté."

Baudry-Lacantinerie is more explicit. While admitting that the Roman superficiary had only un droit réel sur la chose d'autrui, he contends that, in French law, he does not have un simple droit d'usufmect, but truly un droit de propriété. His right is perpetual; unlike a servitude, it is not Iost by non-user. ${ }^{78}$ The author continues: When a superficiary in France owns an edifice and another has title to the soil, we do not' have two parties with undivided interests in the same thing; each is the

a un droit exclusif sur les constructions et plantations adhérant à la surface du sol, on dit que cette dernière a un droit de superficie, et on lo désigne parfois du nom de superficiaire," BAUDRY-LACANTINERIE, op. cit. supra note 71, § 341 .

${ }^{74}$ See Sorm, INSTITUTES (1907)! $\$ \S 70$ et seq. for a description of this right and of a similar agricultural right, emphyteusis.

Heritable building rights (Erbbaurechte) modeled on the right of supcrficies were prevalent in the German law after the Reception. Garers, THE ScIENCE of LAW, (1911); 155; SchUSTER op. cit. supra note 51, § 340, p. 412 et seq.

75 "Le caractère de droit de superficie est contesté encore de nos jours."

Planiol, Traite filementatre (8th ed. 1920) § 2525, p. 781.

${ }^{30}$ Demolombe loc. cit. supra note 72 .

77 See Planiol's discussion of Laurent's differing interpretation of the Belgian law. PLANior, op. cit. supra note 75, § 2526, p. 786.

$78 \mathrm{This}$ paragraph is a free translation and paraphrase of language from BAUDRY-LACANTINERIE, op. cit. supra note 71 , §§ 341, 343.

The Belgian law limits the duration of the right to fifty years by statute. Lor DU 16 JANVIER 1824. 
owner of a divided part of what was once one immovable, but the division is not accomplished, as in the case of the partition of a farm between two heirs, by means of a vertical plane marking on the soil a horizontal line separating the partitioned properties; the division is accomplished by means of a horizontal plane which passes through the foundations of the building or the roots of the plants. ${ }^{29}$ The owner of the soil has that part of the immovable situated below the plane, and the superficiart that which is above. Each one has all the rights and liberties inherent in ownership over the part belonging to him, conditioned on respect of the rights of the other.

In the very language with which he expresses his analysis, Baudry-Lacantinerie thus points to the recognition by the French law of such a vertical division of land as is the subject of our inquiry. Article 664 of the Code provides:

"When different stories of a house belong to different owners, if the title deeds do not regulate repairs and reconstructions, they must be made as follows:

"The main walls and roof at the expense of all the owners, proportionately to the value of the respective stories;

"Fach owner the floor on which he walks;

"The owner of the second story, the staircase leading to it; the owner of the third story, his staircase beginning at the second story; and so on." 80

This section is a further and more explicit recognition of the possibility of story owmership. ${ }^{81}$ Commenting on it, Demolombe tells us that story ownership is prevalent in Grenoble and Rennes, and that examples are also found in Normandy. The most usual occurrence of it, however, results from the division of an estate by the heirs after an ancestor's death, or by the testator in his will. ${ }^{33}$ In such a case, the foundations and the outhouses and appurtenances remain undivided.

Demolombe suggests that three questions about such ownership naturally occur: what are the obligations of the proprietors? what are their rights? what happens in case of the destruction of the building? Of these, he points out, only the

ra "La division s'opère à l'aide d'un plan horizontal qui passe ì extrémité des fondations de la maison ou des racines des plantes."

80 FrENCE CIVI CODE (1803) art. 664. I Cf. the cases, supra note 20, which deal with the reciprocal servitude's which are enforced in the common law. It will be seen that the French law goes further in enforcing contribution for repairs of the foundation and roof than does our law.

81 Demolombe finds a further recognition of such divided property in Article 519, which lists among "immovables by their nature" windmills even though built over the soil of navigable streams. Desrorosse, op. cit. supra note 72, \& 483, ter, p. 394.

821 Demolomibe, Tratse des Servitudes (1858) $\$ 425,6 i s$, p. 505.

8s Ibid,; PlanIol, op. cit. supta note 75, § 2522, p. 781 . 
first is answered by the Code provisions. ${ }^{84}$ If the third were expressly answered, we would have further light as to the real nature of the droit de superficie.

Demolombe discusses the second question, and from his discussion some very interesting implications arise. He cites two decisions holding that the owner of the upper story can build additional stories. One decision even goes so far as to hold that the lower owners are bound, in case the walls as they exist are not strong enough to support the projected stories, to contribute proportionately to rebuilding them. Demolombe, while professing a hesitancy to question the resolutions of these courts, doubts the validity of the rule they establish, and cites authority to a contrary view. He suggests that it is not absolutely correct to say that the owner of the top story would be the sole owner of the space above to the heavens, to make any use he pleases of it, since any additional story places some burden on the lower proprietors that did not originally exist-not only by weakening the walls, but by decreasing the value of the property through increasing the number of inhabitants..$^{.5}$

As to the third question, he points out that no trouble can arise either when there is agreement among the different owners as to the advisability of rebuilding, or when they are all satisfied not to rebuild as before. He refers to authority holding that rebuilding is required if some desire it, even if the others do not, and that the expenses are pro-rated, the unwilling losing all right in the property if not contributing. Demolombe inclines to an opposite view, believing that the land, in case of disagreement, should be partitioned proportionately to the value of the different stories. ${ }^{80}$ Planiol also suggests that after the destruction of the building by fire the various owners become co-tenants in the

84 1 Denrolomise, op. cit. supra note $82, \$ 426$, p. 506. This commentator gives us an interesting discussion of the provisions of Articlo 664, which in some ways changed the old law of the realm. He cites a number of interesting applications of these principles which might profitably bo studied by the common law courts when called upon in the future to pass upon similar questions. Ibid. $\S \S 427-435$, pp. 506-512.

${ }_{85}$ Ibid., esp. p. 515. See for Demolombe's general discussion of the rights of the proprietors, ibid. $\S \S 436-439, \mathrm{pp}$. 512-516. Compare these French cases with the Scottish decision, Watt v. Burgess's Trustee, supra note 66, which apparently conficts with them. Demolombe also seems to believo that the holding in such a situation as gave rise to the litigation in the Scottish cases, Urquhart v. Marshall, supra note 60, and Arrol v. Inches, supra note 64 , would be generally in accord with the result of the former rather than the latter decision-that is, the stratum of the lot conveyed would not be laterally limited by the dimensions of the original story.

\&s Denolombe, op. cit. supra, note 82 , pp. 516-518.

One wonders just what is meant by the word "reconstructions" used in Article 664; why is it not possible to find in it a requirement of rebuilding? 
land as it then stands. ${ }^{8 z}$ If this be the correct view, it follows, as has been said several times before, that the real subject matter of the right is the building and not the portion of space it delimits.

\section{$\checkmark$}

One other suggestion of vertical division to be found in the decisions of common law courts must be briefly noticed. Rights of way for streets, railroads, transmission lines, and those required by similar public utilities, are usually in the nature of easements. Disturbances of easements are actionable wrongs, and in the case of ways of various kinds questions have often occurred because of alleged disturbances which did not affect the surface of the soil over which the way extended. Universally the courts have refused to recognize actions based on acts which did not actually interfere with the exercise of the easement, and the result has been to create an apparent horizontal limit to such easements, outside of which, because the use did not extend so far, no act could give rise to an action. The result of the cases is to give to an easement of way the appearance of a right to the use or even possession (when the easement is exclusive) of a vertically limited portion of the landspace. As an illustration of the notions which occupy the minds of courts because of these circumstances; we may take the followring passages from a recent ease in the Kentucky court:

"The ownership of an easement extends only to such height as reasonably to permit the full and free enjoyment thereof for the purpose for which it was granted or acquired, and no further. The easement holder would be as much a trespasser if he ascended and occupied the realm above the right of way for some purpose not contemplated by the grant as would be a stranger .... In other words, a right of way is a limited estate in land, - limited as to dimension, - width, height, depth, and length, and the grantee must keep within such limitations or he at once becomes a trespasser ... He can protect from wrongful invasion the whole of the right of way. Beyond this, he has no legal concern." 88

8z "Par conséquent si la maison brûle ou si elle est démolie, le sol n'est pas la propriété exclusive du propriétaire du rez-de-chaussée; il appartient indivisément à tous." Pranior, op. cit. supra note 75, § 2522, p. 781.

This defeasibility is not precluded by the many statements that the right of the superficiary is "perpetual." Demolombe, consistently enough, remarks that the right is perpetual escepte soulentent les chances d'ertinetion du droit de propriété, en égard auss differents objets sur lesqucls il repose. The possibility of the property being the space apparently did not occur to him.

88 Per Sampson, J., in Citizens Telegraph Co. v. Cincinnati, NY. O., and T. P. R. R., 192 Ky. 399, 408, 233 S. W. 901,903 (1921). 
Frequently a municipal corporation or public utility acquires, either by virtue of common law rights, or because of statutory enlargements of powers of purchase or condemnation, what purports to be more than a mere easement-a fee of some sort. Sometimes this fee, by analogy to the common law easements, is limited to the purposes for which an easement would have sufficed, and is treated as defeasible and also limited in vertical extent. Thus, a number of Acts of Parliament vesting in municpal organizations the power to acquire the fee to streets have been so construed. In the oft-cited case of Wandsworth Bourd of Works v. United Telephone Co., ${ }^{80}$ the plaintiff sought to enjoin the defendants from maintaining a wire across a street. The wire was strung from the roofs of the houses of the abutting proprietors, and no poles or other surface appurtenances were set in the street. The justices all recognized that the stringing of a wire across one's land, although never in contact with the physical corpus of the property traversed, would be grounds for an action of trespass, yet they denied the plaintiff an injunction. Brett, the Master of the Rolls, expressed his reasons, which met with the concurrence of his colleagues, in the following words:

"I am of the opinion that this Act of Parliament by the use of the word 'street' does not pass any property above or over the street, it only passes property in the street. It therefore passes only that which is the ordinary space occupied by imen or things which use the street as a street. Under these circumstances, it appears to me that no property passed in that part of the air through which, or in which, this telephone wire was placed."

It is implied by the decision that if the wires had been strung through the area of user the board of works would have been entitled to the injunction on the basis of trespass, but, because the wires were strung above the area of user, the board could not be given relief. It looks as if the "street" were a' vertically limited portion of space separately owned, not negativing the ownership of the abutting proprietor above and below its area.91

8913 Q. B. D. 904 (1884).

90 Ibid. 916. Accord: Finchley Flectric Light Co. v. Finchley Urban District Council, [1903] 1 Ch. 437, 441, where Collins, M.R., said:

"The conclusion to be derived from the authorities seems to me to be this: all the stratum of air above the surface and all the stratum of soil below the surface which in any reasonable sense can be required for tho purposes of the street as a street vest in and belong to the local authority."

oI No exact analogies in the decisions of the courts of last resort of tho United States are discoverable, at least with respect to the space above tho surface. Indeed, the more usual construction of the fee titles of municipal corporations and public utilities leaves out vertical limitations, although sometimes retaining defeasibility. Thus, in Town of Ackley v. Central States Electric Co., 204 Iowa 1246, 214 N. W. 879 (1927), we find a dictum to the effect that a municipal corporation may prevent the stringing of 
While this is a special rule, it demonstrates the possibility of the separate ownership of distinct strata of the landspace. The more phases the conception takes, the more easily will it be fully recognized and applied if it can, when tested, accomplish useful legal results.

\section{VI}

The indications are that our courts will soon be called upon to test the utility of the conception. This skyscraper era affords many possible situations to which it may apply. An illustration will point the truth of this remark.

The attention of the laity as well as of the profession has been recently called to a development squarely based upon the belief of counsel that the land space above the surface of the soil is divisible into strata. The application of this belief has been made in transactions so spectacularly important that everyone to whom the underlying theory and the achieving mechanism has been explained has felt in consequence a stirring of the imagination. What is now styled "the world's largest warehouse" -an ephemeral title in this age of incessant construction-will have neared completion or achieved it before this is read; but, whether or not it will then retain its right to the grandiose description now accorded it, it will still be the tangible symbol of an endeavor as boldly conceived by the men of law who prepared the way as by the architect who fathered its substantial existence. It is the Merchandise Mart of Marshall Field and Company built over the tracks of the Chicago and Northwestern Railroad at Wells, Kinzie, and Orlearis Street, and the Chicago river, in the city of Chicago. Companion to it is the Chicago Daily News building erected over land of the Chicago Union Station Company.

These transactions involve what have become known as a railroad's "air rights" - that is, rights to build in the space above the trackage within the limits of the greater cities. ${ }^{82}$ A brief study of the map of any large city shows the vast extent of land surface needed and used by the railroads for their tracks and terminals. This land surface is immensely valuable as real estate, as the carrying charges on it demonstrate; but what gives

wires across the streets to which it has the fee no matter what their height.

92 The following recent articles are testimony to the current interest in this matter: Bell, op. cit. supra note 46; Burritt, op. cit. supra note 49; Becker, Subdividing the Air (1928) 7 TIIIE NEwS 19; A Decd to the Air (editorial) (1929) 32 LAW NoTES 181. In addition, an article entitled Air Rights Swallows Railways (1928) 50 Pop. IIEchamics 227, refers briefly to the legal problems while discussing chiefly the engineering problems in connection with the Daily News venture. 
value to city business property is of course the ability to erect multi-storied buildings bringing in large rentals. Railroading, however, must be done on the surface. The dilemma is that the railroads must require the surface area, and yet pay carrying charges upon the potential earnings of the cubic space many feet up which can never be used for railroading.

The railroads have not been blind to the unfortunate aspects of their position. In this country several attempts have been made to utilize the space over the tracks in cities. The Grand Central terminal or Park Avenue development in New York City is a good example. In that case, however, the land covered by the tracks was not owned by the railroads, but by a terminal company which has leased building rights for terms of twentyone years with two options of renewal. The title was thus retained by the terminal company, and, if the trackage rights were excepted from the subject-matter demised, the result was nothing more than a lease of all the land with easements reserved. ${ }^{.3}$

Several difficulties confront railroad companies in the development of the space over their lines. In the first place, being colporations with limited powers only, they cannot ordinarily engage in the real estate business on a wide scale.94 They cannot build long blocks of skyscrapers and lease them; similarly, they cannot make wholesale leases of the space to others who might themselves build. Then, too, railroad financing is almost without exception founded upon general mortgages or trust deeds underlying bond issues, covering of course the real estate of which the rights of way are a part. Any structure as pelmanent as a twenty-story building would become subject to the liens of the mortgages or trust deeds. Building leases to others are prevented.

It is because of these and similar considerations that the railroads have been experimenting with the conception of separately owned strata of space. In all of the general incumbrances of railroad property there can doubtless be found provisions for the release of the portions not needed for railroad operations. These provisions of course vary. Whatever the variance, they permit the release for conveyance to others of unnecessary or superfluous land. It has therefore occurred to counsel for some of these companies to take advantage of these provisions by conveying space above the tracks free from the general incum-

\footnotetext{
93 Burritt, op. cit. supra note 49 , at 39 .

94 The trouble which the Pullman Compang had on the erection of its building in Chicago is an illustration of the limitation the doctrine of ultra vires places on the powers of railroads. Reference is made in note 100 infra to difficulties of this sort which apparently still confront British railways.
} 
brances. The two transactions already mentioned have been undertaken on this basis. The transaction between the Ghicago Daily News and the Chicago Union Station Company cannot be described more tersely than in the language of one who, as counsel for the News, was himself in large measure responsible for the solution of the difficulties:

"The Union Station deeded to the Daily News the entire interest in the property in question, esccepting therefrom the space below a designated plane, and excepting from the exception the right to run columns and foundations through the excepted space. The railroad thus expressly disposes of all the property except that below the specified plane, which excepted property includes the tracks and right of way that cannot be got out from under the mortgage." 95

This transaction truly represents what the same writer later calls it_ "a conveyance of the air lot with a right to support." so

The other transaction mentioned, that between the Chicago and Northwestern Railroad and Marshall Field and Company, is, if anything, even more of a pioneer in this field. Here, instead of positive easements of support, the grantee desired to have the title to the space to be occupied by the caissons upon which the proposed building was to rest and by the steel supporting columns extending from the caissons to a point above the space reserved for the railroad, as well as to have the title to the space . above that. To make possible a conveyance accomplishing this, the land was resubdivided, and a plat recorded.9r Instead of the usual sort of a plat, this one indicated what was intended to be an identification of lots, not by surface markings, but by three-dimensional descriptions.

${ }^{85}$ Bell, op. cit. supra note 46 , at 261.

So IIr. Bell tells us that this convejance is similar to those made by the Pennsylvania Railroad in New York and by the Reading Railroad in Philadelphia. Ibid. 264.

No question of ultra vires or similar objection can be urged in nllinois to such a conveyance by any nlinois railroad, union depot, or terminal company to which a recent Illinois statute is applicable. Ir. Rev. STAruTEs (1929) c. 114, $\$ 174$ a provides that, where lands owned in fee, or different levels of them, can be devoted to other than railroad uses "without unreasonable impairment of the remainder for railroad purposes," the company "may improve, utilize, and develop the part of such real estate susceptible of such other use or uses," and "may subdivide the separate level or levels susceptible of such, other uses into lots and blocks, . . . and may sell, convey, and transfer to purchasers any separable part or parts (singly or combined) of such real estate at, above, or below the natural surface of the ground ... or may lease to others." Provision is made for the approval of all such developments, conveyances, and leases by the Mlinois Commerce Commission. This is a statutory recognition of the possibility of vertical division of land space.

${ }^{97}$ Power so to subdivide is specifically granted in the statate just quoted. 
The architect had already drafted his plans for the proposed building. To provide for the caissons called for in his plans, the plat and its accompanying data identify some six hundred caisson lots. They are described as:

"All the land, property, and space at and below horizontal plane zero Chicago City Datum in six hundred complete cylinders formed by projecting vertically downward from said plane the circles forming the boundaries of said lots as represented on the plat." 88

Zero Datum is about five feet below the surface of the soil at this point. Above each caisson lot is a rectangular prism extending to a point about eighteen feet above the surface, or, more accurately, twenty-three feet above zero Chicago City Datum. They are described as:

"All the land, property, and space in six hundred quadrangular" prisms of the horizontal dimensions shown on the plat, extending vertically between horizontal planes respectively at zero and twenty-three feet above Chicago City Datum."

Then there is what is designated on both plat and deed as the "aix-lot"-a bit of space described as:.

"All the land, property, and space at and above a horizontal plane twenty-three feet above Chicago City Datum bounded on the Elast by Wells St., on the North by Kinzie St., on the West by the Franklin-Orleans Viaduct, and on the South by the Chicago River."

The caisson lots, prism lots, and the air-lot so identified have all been granted in fee to Marshall Field and Company. The railroad, by necessary implication, retains the title to the remainder of the original plot of ground. No easements of support are necessary, nor are any granted. ${ }^{99}$

The boldness of conception from which resulted this threedimensional subdivision of the land space has an appeal both to the layman and to the lawyer. Whether it is more or less. practical than the Daily News conveyance remains an open question. Time may prove that it is too inflexible for the purpose for which it was devised. Such criticism as the plan may

${ }^{88}$ These descriptions are quoted by Becker, op. cit. supra note 92, at 20 . Mr. Becker, who is vice-president of the Chicago Title \& Trust Co., was himself one of the authors of the plat.

09 The importance of the undertaking is realized when we are reminded that the cost of the Merchandise Mart is estimated at $\$ 30,000,000$, and that it is to have, when completed, a total floor space of 4,000,000 squaro feot, twice the size of the Furniture Mart in Chicago. See Burritt, op. cit. supra. note 49. 
a bold precedent which will undoubtedly have its influence on the professional attitude toward the nature of land and the possiprove to deserve cannot detract from the fact that it serves as bility of its vertical division. ${ }^{100}$

100 Oddly enough, certain earlier English cases dealing with anslogous problems of zailroad corporations have been unmentioned in all the dis: cussions over these dealings with "air rights."

In Irulliner v. Ifidland Ry. Co., 11 Ch. D. 611 (1879), the railway had sold to the plaintiff tracts on either side of the right of way, together with a way between the tracts which led through an arch beneath the railway station and which was elevated. The land and way were sold as superfluous land within the meaning of the Land Clauses Act, defining them as ". . . Iands acquired by the promoters of the undertaking under the provisions of this or the special Act ... but which shall not be required for the purposes thereof." The question. whether the way through the arch was superfluous land arose when the railway sought to close the arch. The court anstwered in the negative, and upheld the right of the railway to close the arch. Jessel, II.R., reasoned as follows:'

"The whole thing, the land below the arches, and the pavement, works, and passenger station above the arches-all form the railway station, and is, according to the definition, part of the 'railway and works.' Now for what purpose is that to be used? It is to be used for the purposes of the Act, that is, for the general purposes of a railway. ... It rould be a very odd thing, even if there were no enactment to the contrary, to allow a corporation formed to hold land for a special. purpose, and to talke that land compulsorily from the owners only for that purpose, to devote the land to another purpose, or to alienate the land generally under any notion of the rights of an ordinary proprietor." Ibid. 619.

The Mraster of the Rolls added that the railway company did not have the ordinary rights of proprietors, but held the lands to use "merely for the special purposes" of its creating act. He pointed out that the "land" under the arch was required for support. "It is quite plain," he conclnded, "that the land cannot be treated as land not required for the purposes of the railway." Ibid. 621 .

The next year the case of In re IIetropolitan Dist. Rg. and Cosh, $13 \mathrm{Ch}$. D. 607 (1880), was decided. The railway had been run underground, and sought to convey the land above the tunnel as superfiuous land. The conveyance was attacked. In the court below, Fry, J., pointed out that the railway, in condemning the land, had to take it in its full vertical extent, but concluded:

"However convenient it may be for the company to sell, or to grant building rights over, and building leases of, the crown or roof of their tunnel, they have no title to do so under the statutory powers with which they are invested." Ibid. 612.

The decision below was upheld on appeal. The ifulliner case, sttpra, was cited, and new reasons were advanced. Jessel, Mr.R., suggested that the requirement that the railway dispose of its superfluous lands vithin a specified period argued against the right of the railway to divide its land by a horizontal plane:

"It would be an extraordinary thing if a railway company were to be compellable to decide as to the necessity of retaining the horizontal strats of every piece of land .. . from the beginning to the end of their line." Ibid. 61T.

Some of Jessel's language indicates that he would have had difficulty 
Both arrangements, despite their differences in the matter of support, are unqualified recognitions both of the ownership of space, and of its vertical division. As such, they demonstrate why the present inquiry is not a purely academic one, but rather is anticipatory of problems which must some day in the not greatly distant future be settled by the courts. They emphasize the tremendous value of rights to. the possession of the space over land, and they suggest a few reasons why man may find it profitable to make divisions of it in strata. That other reasons in other situations may and will compel similar arrangements cannot be doubted. The influence of economic conditions on

in recognizing such a division even when made by an ordinary proprietor, but the decision is particularly based on the statutory powers of tho railroads.

There are, however, other intimations in these cases which are seized upon and enlarged in later decisions arguing for the right of an ordinary proprietor to make such divisions. Thus Baggallay, L.J., doubted the decision of his colleagues in the Cosh case, supra, saying:

"Now if, after the railway has been completed, the mass of earth above the tunnel, being such that any subsequent repairs must of necessity be done from the inside and not from the outside, I should, as at presont advised be disposed to hold that the company might make a severance by a horizontal division of the land so acquired, retaining all below the railway and a certain portion above the railway within limits to be regulated by the nature of the case." $13 \mathrm{Ch}$. D. at 623 .

In Rosenberg v. Cook, 8 Q. B. D. 162 (1881), the nature of what passed by a similar ultra vixes conveyance was stated to be more than a rovocable easement or license; it was a bare possession, good against all the world except the railway company, and analogous to the right of a disseisor or trespasser.

In Midland Ry. v. Wright, [1901] $1 \mathrm{Ch}$. D. 738, a disseisor of the surface over a railway tunnel was held to have acquired a title by adverse possession. Byrne, J., said:

"I consider that the defendant and his predecessors in title have acquired by possession title to the surface of the land, with so much of what is beneath as is necessary for the enjoyment of it, subject to the right of the plaintiffs to the tunnel and to so much of the underlying and superincumbent strata as is necessary for its due and proper enjoyment as and for a tunnel." Ibid. 744 .

Reliance for this decision was placed upon Rosenberg v. Cook, supra, and the implication of these cases is that the Mulliner and Cosh decisions, both supra, must be ascribed solely to the inability of railways, with their limited statutoiry powers, to convey such horizontal strata, and not to any inherent inability of the average fee owner to make such divisions. In fact, the clear implication is that such owners can make conveyances of horizontal strata.

The rule crystallized by the Cosh case has been strictly followed both in England and Scotland (where the English acts apply), so that, unless changes have been made in their statutory powers, British railways cannot develop their "air rights" in the manner of the two. Chicago transactions. See Re Lancashire \& Yorkshire Ry. and Earl of Derby's Contract, 100 L. T. 44 (1908) ; Glasgow \& S. W. Ry. v. Caledonian Ry., 19 Scot. L. R. 547 (1882). 
legal institutions is not questioned in current legal philosophy. Here is a place where practical economics will exert an influence; here are the germs of revolutionary conceptions. ${ }^{302}$

We have seen that there have been endeavors to convey as separate holdings portions of space lying above the surface, defined by horizontal as well as by vertical planes, and not identified by solid matter occupying them. No reason has been found in the cases why such conveyances cannot be made. No established policy of the law appears to stand in their way. 102 The cases offer few precedents, but those which seem to ignore the ownership of space and pay attention only to the matter occupying space do not negate the possibility of conveying stratified space by proper words. The facts of the particular cases, the improbability of any intention of the parties under the circumstances to stratify the land, and the lack of any urgent reason why such a construction should have been given-these are explanations which readily occur. That the courts have relied on such explanations is an argument for the recognition of the legal soundness of such transactions as prepared the way for the Marshall Field and Daily News buildings. Then, too, the cases give some encouragement. Results sometimes reached, more frequently the language used, show that our courts will not be unwilling to give such recognition when called upon to do so.

101 Burritt remarks: "If we are to believe the principal architects and builders of the country, the upward ascent has only begun. . . . Real estate is no longer a groundlevel consideration. Its chief value in many zections of our cities is-or presently will be-from the ground up." Burriti, loc. cit. supra note 49 .

The newspapers within the last couple of years carried an estimate of Charles IIarkham, chairman of the board of the Illinois Central Railroad, that the air rights over the company's tracks in Grant Park, Chicago, were worth $\$ 100,000,000$. No one has questioned the conservativeness of the estimate.

Another suggested use of the air rights over railroads has been made within the year by a committee of the city council of Chicago, headed by Alderman Irassen, which has advocated building super-highways over the railroad trackage.

102 Professor Kocourek believes that considerations of convenience should argue against recognition of such strata ownership. The solution of our problem, he suggests, should be "one of policy and not one of logic." The State is interested in having land divisions on a basis "which does not present too much dificulty in identifying the thing elements which are to be taxed." He suggests that the "legal difficulties of adjusting the legal relations of each owner to each of the others" where several strats are separately owned "would be insuperably complex and would work: against economic utility." He concludes that "the doctrine is highly inconvenient in any case, and the results sought could better be attained by refusing to recognize ownership of land as horizontally divisible and by treating such departures as jura in re aliena." Kocougsk, JuRnt RELATIONS (1927) 338-339. 
While the decision of the courts upon matters still more or less academic can never be predicted with any assumption of certainty, we are still entitled to believe that some day the stratiffcation of landspace will be commonly accepted. Indeed, the trend of economic development, so often the presage of the legal future, leads to some degree of confidence in this belief. 